\title{
Long-Term Protection of Uranium Mill Tailings
}

\author{
P. A. Beedlow
}

J. N. Hartley

April 1984

Prepared for the U.S. Department of Energy under Contract DE-AC06-76RLO 1830

Pacific Northwest Laboratory

Operated for the U.S. Department of Energy by Battelle Memorial Institute 


\title{
DISCLAIMER
}

This report was prepared as an account of work sponsored by an agency of the United States Government. Neither the United States Government nor any agency thereof, nor any of their employees, makes any warranty, express or implied, or assumes any legal liability or responsibility for the accuracy, completeness, or usefulness of any information, apparatus, product, or process disclosed, or represents that its use would not infringe privately owned rights. Reference herein to any specific commercial product, process, or service by trade name, trademark, manufacturer, or otherwise, does not necessarily constitute or imply its endorsement, recommendation, or favoring by the United States Government or any agency thereof. The views and opinions of authors expressed herein do not necessarily state or reflect those of the United States Government or any agency thereof.

\author{
PACIFIC NORTHWEST LABORATORY \\ operated by \\ BATTELLE \\ for the \\ UNITED STATES DEPARTMENT OF ENERGY \\ under Contract DE-AC06-76RLO 1830
}

\begin{tabular}{|c|c|}
\hline \multicolumn{2}{|c|}{$\begin{array}{c}\text { National Technical Information Service } \\
\text { United States Department of Commerce } \\
5285 \text { Port Royal Road } \\
\text { Springfield, Virginia } 22161\end{array}$} \\
\hline \multicolumn{2}{|c|}{$\begin{array}{l}\text { NTIS Price Codes } \\
\text { Microfiche A01 }\end{array}$} \\
\hline \multicolumn{2}{|c|}{ Printed Copy } \\
\hline Pages & $\begin{array}{l}\text { Price } \\
\text { Codes }\end{array}$ \\
\hline 001-025 & $\mathrm{A} 02$ \\
\hline 026-050 & $\mathrm{A} 03$ \\
\hline $051-075$ & A04 \\
\hline $076-100$ & A05 \\
\hline $101-125$ & $\mathrm{~A} 06$ \\
\hline $126-150$ & $\mathrm{~A} 07$ \\
\hline $151-175$ & $\mathrm{~A} 08$ \\
\hline $176-200$ & $\mathrm{~A} 09$ \\
\hline $201-225$ & A010 \\
\hline $226-250$ & A011 \\
\hline $251-275$ & A012 \\
\hline $276-300$ & A013 \\
\hline
\end{tabular}


DOE/UMT-0218

PNL-4984

UC -70

LONG-TERM PROTECTION OF URANIUM MILL TAILINGS

P. A. Beedlow

J. N. Hartley

April 1984

Prepared for the U.S. Department of Energy

under Contract DE-AC06-76RLO 1830

Pacific Northwest Laboratory

Richland, Washington 99352 



\section{ABSTRACT}

U.S. Environmental Protection Agency standards for the cleanup and disposal of inactive tailings sites require that control measures for disposal of tailings be designed to be effective for up to 1000 years if reasonably achievable, and, in any case, for 200 years at least. To control the escape of contaminants over such long periods, containment systems must be capable of adjusting to changing environmental conditions. Elements of a containment system include surface covers, biotic barriers, radon barriers, and, in some cases, liners. Each element of the system affects the others, and the whole system responds to the surrounding environment. Interaction is facilitated primarily by soil moisture. Consequently, the control of soil moisture is critical to the effectiveness of containment systems.

Protective covers are necessary to prevent disruption of the containment system by physical or biological factors, to provide for the effective functioning of the radon barrier, and to prevent infiltration of excess water that could cause leaching. In order to design protective covers, a working knowledge of the factors and processes impacting tailings piles is required. This report characterizes the major factors and processes, and presents generic solutions based on current research. 



\section{CONTENTS}

ABSTRACT $\ldots \ldots \ldots \ldots \ldots \ldots \ldots \ldots \ldots \ldots \ldots \ldots \ldots \ldots \ldots \ldots \ldots \ldots \ldots \ldots \ldots \ldots \ldots \ldots \ldots \ldots \ldots \ldots \ldots$

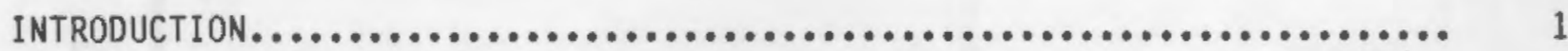

TAILINGS CONTAINMENT--A DYNAMIC SYSTEM....................... 3

LONG-TERM PROTECTION REQUIREMENTS............................ 5

FACTORS AFFECTING LONG-TERM STABILIZATION..................... 9

EROSION................................................. 9

Wind............................................... 9

Surface Run-0ff..................................... 10

Flood Intrusion..................................... 12

Settlement and Mass Wasting............................ 13

BIOTIC INTRUSION..................................... 13

Mechanisms of Contaminant Escape........................ 14

Factors Affecting Root Depth and Animal Burrowing........... 15

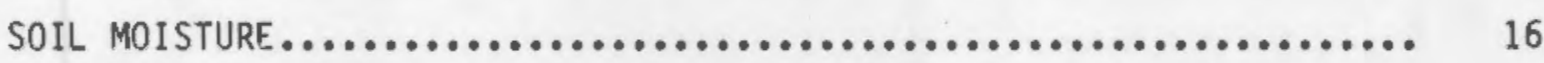

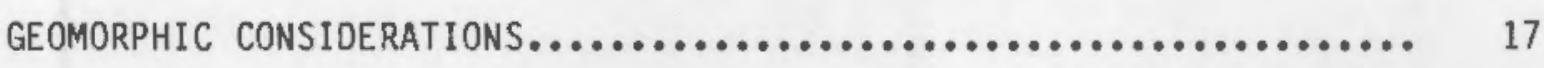

Geomorphic Hazards.................................. 18

Impact of Geomorphic Change on Flood and Gully Intrusion....... 20

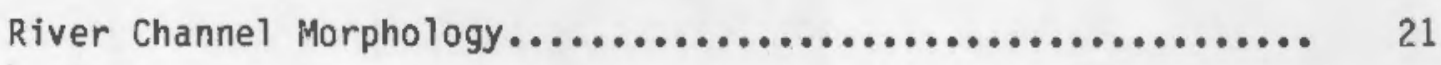

Gully Migration..................................... 22

ENGINEERING STABILITY.................................. 23

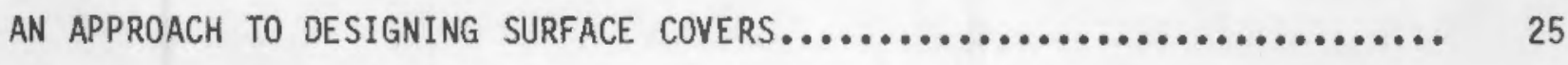

DESIGN TOOLS AND CONCEPTS................................. 31

BASIC DESIGNS FOR PROTECTIVE COVERS...................... 31

Effectiveness of Vegetation for Erosion Control............. 36 
Effects of Biological and Radon Barriers on Vegetation........ 41

Effects of Rock Material on Vegetation and Soil Moisture...... 42

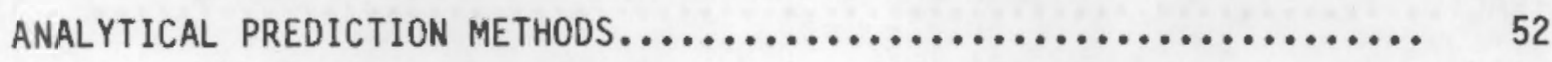

Erosion............................................. 52

Biotic Intrusion..................................... 55

Soil Moisture....................................... 56

RELATED RESEARCH.......................................... 59

REFERENCES.................................................. 63 


\section{FIGURES}

1 El ements of the Tailings Containment System................... 4

2 The Fluvial System..................................... 19

3 Decision Tree for Designing Protective Covers for Inactive Mill Tailings ........................................ 26

4 Basic Designs for Long-Term Erosion Protection of Uranium Mil1 Tailings Impoundments................................... 32

5 Basic Cover Designs Using Vegetation........................... 35

6 Control of Plant and Animal Intrusion..................... 36

7 USLE Estimates of Soil Loss from Sites Near Inactive Tailings Piles in Three Climatic Regions of the Western United States........ 38

8 USLE Estimates of Soil Loss from Sites Near Inactive Tailings Piles in the Western United States, Comparing Common Vegetation Types........................................ 39

9 Multilayer Radon Barrier.............................. 47 


\section{TABLES}

1 Plant Community Types Identified at Soil Sites in the Vicinity of 20 Uranium Tailings Piles...........................

2 USLE Estimates of Soil Loss as Reduced by Applying Crushed Stone to the Soil Surface........................................ 40

3 Cumulative Water Loss from Lysimeters in Experiment 1, Comparing the Effects of Rock Size on Soil Water Loss........................

4 Cumulative Water Loss from Lysimeters in Experiments 3 and 4, Comparing the Effects of Rock and Vegetative Covers on Soil

Water Loss.................................................

5 Matric Potential in Soils Under Vegetation and Rock

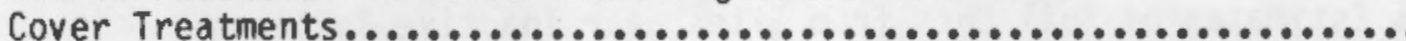

6 Volumetric Moisture Content at Two Depths of the Test Plot

for Two Dates in 1982. 


\section{INTRODUCTION}

Uranium mill tailings are waste products of the uranium extraction process. Tailings contain hazardous compounds that, if released into the atmosphere and groundwater in sufficient quantities, are a potential threat to human health and the environment (NRC 1980). To provide for safe, environmentally sound disposal and control of uranium mill tailings, Congress enacted the Uranium Mill Tailings Radiation Control Act of 1978 (Public Law 95-604, 42USC7901). Subsequently, the U.S. Environmental Protection Agency (EPA) established standards for tailings disposal, limiting radon emissions into the air to $20 \mathrm{pCi} \mathrm{m} \mathrm{m}^{-2} \mathrm{~s}^{-1}$ on an annual average basis (EPA 1982, 1983). The design life of the impoundment is to be 1000 years where practicable, but 200 years at least. Groundwater protection is based on state and local standards.

To facilitate the design of containment systems that will meet the EPA standards, the U.S. Nuclear Regulatory Commission (NRC) and the U.S. Department of Energy (DOE) are sponsoring research at Pacific Northwest Laboratory $(\mathrm{PNL})^{(\mathrm{a})}$ to develop the necessary technology (0'Brien 1981; Foley 1983). Asphalt and earthen materials have been evaluated for use as radon barriers (Hartley et al. 1983) and as liners to control leaching (Buelt et al. 1981). To maintain long-term effectiveness, a containment system must be protected by a surface cover from wind and water erosion, chemical and physical degradation, and biological disturbance. A major activity in the DOE Uranium Mill Tailings Remedial Action Project (UMTRAP) was the development of guidelines for stabilization of tailings covers.

The overall objective of the research conducted at PNL on surface stabilization was to develop guidelines for the use of vegetation, rock, or a combination of the two to stabilize the surface. The research effort concentrated on developing generic solutions to the problems of surface erosion, biological intrusion, soil moisture, and geomorphic hazards, and has provided options for remedial action designs.

(a) Operated for the DOE by Battelle Memorial Institute. 



\section{TAILINGS CONTAINMENT--A DYNAMIC SYSTEM}

The goal of a tailings containment system is to minimize the escape of hazardous materials. Pollutants can escape through leaching, surface run-off, gaseous diffusion, biotic transport, or any combination of these mechanisms. Each component of the containment system (Figure 1) is designed to minimize the impact of one or more of these factors. Leaching is controlled by liners, by the inherent buffering properties of underlying soils, or by control of water infiltration. Radon barriers are designed to limit radon gas diffusion. Chemical and physical barriers prevent intrusion of plants and animals into tailings. Surface covers protect the impoundment from erosion that could render radon barriers ineffective or lead to direct transport of tailings material.

The components of the containment system do not function independently. In designing a containment system to meet requirements for radon control, prevention of leaching, and long-term stability, the interaction between soil moisture and the system components is critical and must be well characterized. For example, the amount of moisture affects radon attenuation by earthen materials because radon release is inversely related to soil moisture content (Mayer, Beedlow, and Cadwell 1981; Hartley et al. 1983). The design of an effective liner must allow for the amount and rate of water passing through the tailings (Buelt et a1. 1981). The amount and depth of soil moisture affects the growth of plant roots, and influences the need for animal intrusion barriers.

Containment systems should be viewed as dynamic systems, with each component affecting the others and responding to the surrounding environment. Components should be designed in an integrated manner that minimizes the release of toxic elements. Designing a containment system will involve a number of trade-offs. Increase the amount of soil moisture to reduce radon flux and the chance of biotic intrusion or erosion increases; reduce the erosion potential by thickening rock covers and increase the amount of water in the system--and so on. In addition, the effect of potential geomorphic hazards on the cover system must be considered. Optimization of system components is a vital part of containment design. 


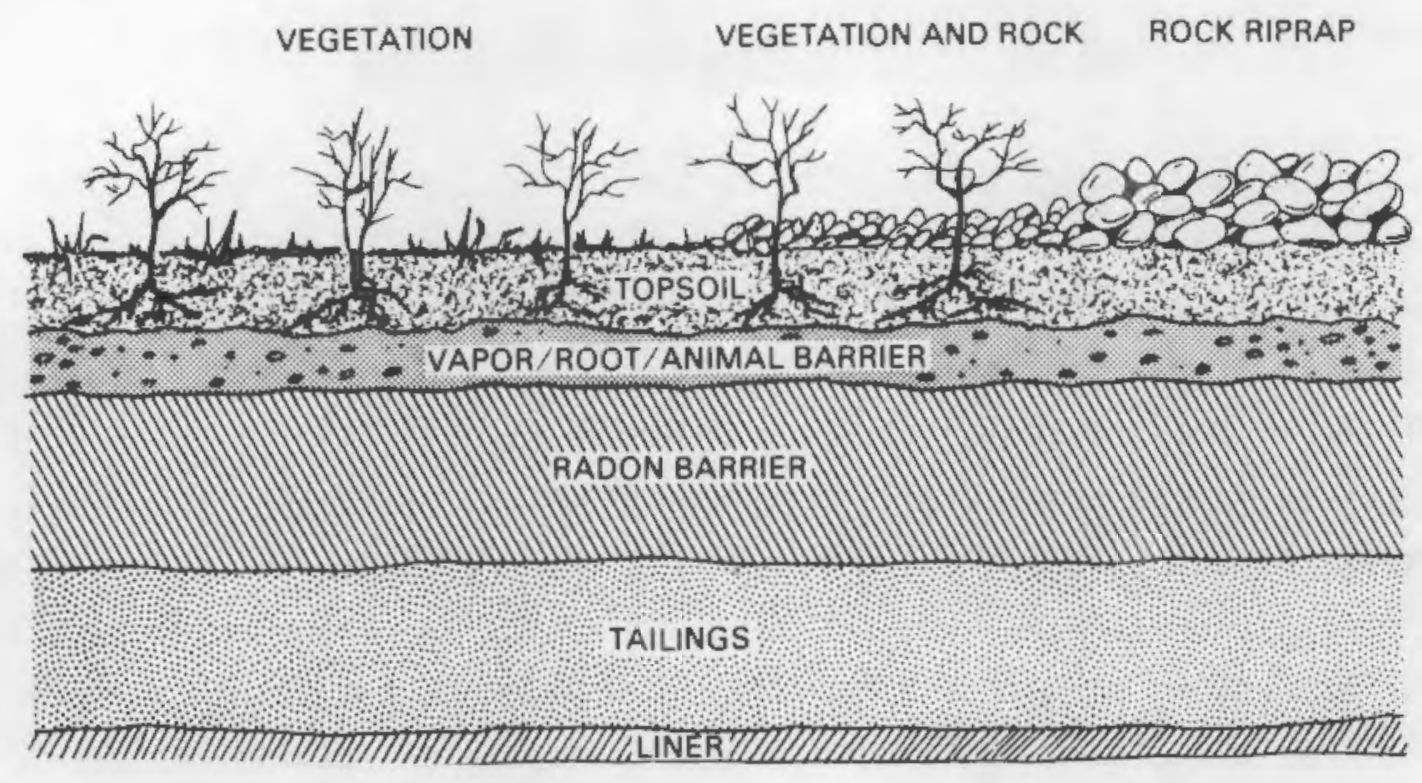

FIGURE 1. Elements of the Tailings Containment System

Because soil moisture is a factor in the functioning of all components, the ability to control the amount of moisture in the system allows a greater range of design options. Soil moisture control can be achieved by a proper, site-specific mix of rock and vegetation in the protective cover. The depth to which roots penetrate a cover can be controlled through proper placement of root barriers. For example, maximal soil moisture could be achieved by placing thick rock covers on the surface to reduce evapotranspiration and by placing a root barrier close to the surface. In this way, precipitation quickly infiltrates beyond the rooting zone. Minimal soil moisture could be achieved by maximizing vegetative cover and root development to extract the water. 


\section{LONG-TERM PROTECTION REQUIREMENTS}

Ideally, a tailings containment system should reduce the potential radiation and chemical hazard to an acceptable level immediately, and provide this control for the anticipated life of the hazard. Unfortunately, because of the long 1 ifetimes of the radioactive contaminants (thorium-230, for example, has a half-life of $\sim 80,000$ years) and the presence of other toxic chemicals, the tailings are likely to remain a biohazard indefinitely. Because of the difficulty in predicting long-term erosive forces, stabilization requirements have centered on the relatively near term, and have allowed for considerable design flexibility.

Natural forces such as floods, heavy rains, windstorms, tornadoes, earthquakes, and glaciers may disrupt the tailings impoundment (Nelson and Shepherd 1978). These forces are of ten interrelated, and are of ten beyond our power to control. The EPA believes that stability against natural forces is achievable for up to a few thousand years by designing protective measures on a caseby-case basis and taking site-specific factors into account (EPA 1983). Predictions of stability become less certain as the time period increases. Designing protective covers to resist erosive forces that result from long-term geological processes and climatic change is not technologically or economically feasible at this time.

Final cleanup and disposal standards for the inactive tailings sites (EPA 1983) require that for disposal of tailings, control measures shall be designed to be effective for up to 1000 years if reasonably achievable, and, in any case, for at least 200 years. The EPA is allowing this flexibility because 1) a wide range of climatic, edaphic and geomorphologic characteristics exist at the inactive sites, 2) projecting the performance of control measures over long time periods involves many uncertainties, and 3 ) providing reasonable assurance of long-term stability may entail great expense.

The objectives of tailings control and stabilization, then, are to prevent misuse by man, to reduce radon emissions and gamma radiation exposure, and to avoid the contamination of 1 and and water by preventing natural erosion. Longterm stability for periods less than 1000 years is likely to be affected 
primarily by human disruption, by the occurrence of floods, rainstorms, and windstorms, and by chemical and physical processes.

Flooding caused by large rainstorms, rapidly melting snow, or local cloudbursts could have a significant impact on the impoundment systems. Increased moisture in the cover from flooding or infiltration may make steep slopes unstable, with eventual loss of cover and dispersal of tailings. The anticipated size of a flood can be determined from an area's historical stream flow data and from techniques of geomorphology. The "design flood" is that adopted as the basis for flood protection measures after considering both hydrologic and economic factors. In most areas, the characteristics of relatively frequent floods, such as the 50-year flood, have been well established, and engineers routinely design facilities protected from such events. Where the failure of flood protection systems could result in loss of lives and great property damage, however, a design based on the probable maximum flood (PMF) may be justified. The PMF is the largest flood that is expected to occur in a given region during that climate era; however, there is always a chance that an actual flood will exceed the design flood. Also, with changes in climate, the frequency and size of floods may change.

Uncertainties in design specifications and performance may affect the practicality of long-term flood protection systems. The characteristics of long-term recurrence floods, such as the 1000-year flood, are usually much less certain than those occurring more frequently. Only a very conservatively designed system would be able to satisfy long-tem flood protection requirements. If those requirements could not be satisfied at the present tailings pile location, the tailings would have to be moved to a new site where flooding conditions are more manageable.

The frequency and intensity of windstorms and tornadoes are considered historically predictable. With a suitable cover over the tailings and protection of the surface against wind erosion, severe winds should pose little threat to the cover integrity.

The number and magnitude of past earthquakes in an area is suggestive of the probability of recurrence. In the event of an earthquake of greater intensity than controls were designed to withstand, at least a partial control 
failure can be expected, al though the quantity of tailings released may be small. There is no way to ensure that a cover design is completely fail-safe against earthquake damage.

Because of the magnitude of the forces associated with glaciation, no portion of a tailings impoundment would be likely to survive even a small, relatively short-term glacier. The likelihood of continental glaciation in the western United States, even far into the future, however, is remote. Increased valley glaciation in the west is a possibility. Several glaciers exist high in the Rocky Mountains, where heavy glacial activity existed as recently as 10,000 years ago. An increase in valley glaciation is likely over the long term. Previously glaciated mountain valleys are less desirable as tailings control sites than are nonglaciated sites, such as flat terrain or valleys created entirely by stream erosion. The possibility of valley glaciation should be considered in designing the long-term protection of the tailings impoundment.

Human activity such as excavating, drilling, or using the surface land for grazing and tilling could disrupt controls or accelerate natural erosion processes at the tailings site.

The Uranium Mill Tailings Radiation Control Act requires that uranium tailings control sites be owned by an agency of the federal government and licensed by the NRC or its Agreement States. Such federal responsibility should control any human activity that might disturb the isolation of the tailings for as long as that responsibility is exercised. The EPA has suggested, however, that reliance should not be placed on institutional controls for more than 100 years (EPA 1978). While institutional control is in effect, it should be possible to detect and remedy defects due to wind or water erosion. This should provide some assurance of continued stability against natural forces for a longer period of time. A thick earthen cover and effective surface stabilization could protect the tailings against degradation and human intrusion after institutional controls have become ineffective.

In summary, then, protective covers for uranium mill tailings are intended to prevent the disruption of the containment system by physical or biological factors, to provide for the effective functioning of the radon barrier, and to prevent infiltration of excess water that could cause leaching. A protective 
cover must resist wind and water erosion, especially that resulting from intense storms. The materials must be durable, able to provide protection for the design 1 ife of the containment system. The surface cover must protect the engineered radon barrier from root penetration, burrowing animals, and cracking. To control the infiltration of excess water, a protective cover must provide for the establishment of vegetation, or be engineered to drain water from the pile. At the same time, some water infiltration may be desirable to maintain moisture in the radon barrier.

Designs to satisfy the above requirements must be tailored to specific conditions at each site. While generic requirements and solutions need to be systematically applied to each site, a single standard design cannot be expected to be appropriate or even necessary at each site. Final designs will depend primarily on site-specific problems and the local availability of suitable cover materials. 
FACTORS AFFECTING LONG-TERM STABILIZATION

This section will characterize the problems associated with protective cover design. Erosion, biological intrusion, and soil moisture are the major factors that affect the design, while geomorphic conditions at the site must also be taken into account.

EROSION

The most obvious role of protective covers is to control potentially disruptive erosive forces: wind, surface run-off, flooding, settlement, and mass wasting. Details of these erosion processes as they affect uranium mill tailings piles have been reported el sewhere; ${ }^{(a)}$ summaries based on these publications are presented below.

Wind

Surface wind velocity, soil conditions and particle size, surface roughness, and tailings shape are the primary factors affecting wind erosion. Particle size determines if and how the particle can be moved. Saltation, suspension, and surface creep are recognized forms of particle movement. Soil conditions that affect wind erosion are soil moisture, organic material, and cloddiness or cohesiveness. Surface roughness can decrease or increase erosion. A rough surface lowers the surface wind velocity more than does a flat surface, but the roughness can increase turbulence to cause increased surface wind velocity. The primary configuration factors influencing wind erosion on a tailings pile are: 1) length along the prevailing wind erosion direction, 2) height above the existing terrain, and 3) slope length and steepness.

Vegetation and surface rock tend to reduce wind erosion. Organic material resulting fron the decomposition of plants imparts shear strength and resistance to movement. The extent to which soil loss is reduced by vegetation depends on the height, length, density, and concentration of the vegetation.

(a) Bagnold 1954; Bander 1982; Nelson et al. 1983; Schumm and Chorley 1983; Voorhees et al. 1983; Wal ters 1982, 1983; Young, Long, and Reis 1982; Zellmer 1981. 
Surface particles that are $>0.81 \mathrm{~mm}$ in diameter are generally resistant to movement by wind (Cooke and Warren 1973). Consequently, a continuous layer of gravel would prevent soil loss even in the absence of vegetation.

The potential for soil loss due to wind erosion appears to be minor compared to water erosion over the long term. If tailings are adequately protected against water erosion, wind erosion should be minimal in most cases. Surface Run-off

Water transports soil by raindrop impact, surface flow, and flow within the upper soil layer, and by forming and enlarging networks of rills and gul1ies. Raindrops detach soil particles and can initiate downhill movement of material. Soil material in solution and suspension within the upper soil layer(s) is transported by a process termed through-flow. Water flowing over the soil surface is called overland flow. Erosion from overland flow can be divided into sheet, rill, and gully erosion. Sheet erosion is the removal of thin layers of soil from slopes. Rill erosion occurs as water is concentrated into channels. Continued development of rills leads to the formation of gullies. Once gullies form, they can grow very rapidly.

The detachment and movement of soil particles by raindrop impact is important in initiating soil erosion. The major factors affecting the erosive force of raindrops are drop mass, size, size distribution, direction, rainfall intensity, and raindrop teminal velocity. The detachability and transportability of the soil and the amount of vegetation determine the ease of soil movement by raindrop impact.

On sloped surfaces, soil particles set in motion by raindrop impact can be carried downill by thin films of water. The direct removal of soil particies by sheets of flowing water (sheet erosion) is a minor erosion process; the water generally does not develop erosive velocities.

Water flowing at a sufficient velocity initiates the movement of soil particles by concentrating flow into rills. Rills form at a critical distance from the top of a slope that corresponds to the development of enough velocity to initiate particle movement. The development of this critical velocity is al so controlled by the surface roughness, flow intensity, and vegetation. 
When the eroding force exerted by concentrated flowing water exceeds the resistance of the earth material in which it is flowing, gully formation occurs. A gully can be defined as a relatively deep eroding channel that has recently formed where no well-defined channel previously existed. Gully formation is rapid (sometimes within hours) and progressive. Sloped portions of tailings piles are particularly susceptible to gully formation.

Gullies can be formed by either saturation overland flow or Horton overland flow. Saturation overland flow results from lateral deflection of percolating water due to permeability decreasing with depth. If rainfall exceeds infiltration for a sufficient length of time the soil layers become saturated and the lateral subsurface flow is deflected toward the surface. When the soil becomes saturated to the surface, overland flow occurs. Saturation overland flow can occur under lower rainfall intensities than those required for Horton overland flow if the rainfall is sustained. Saturation overland flow generally forms gullies that are extensions of existing channel systems and can therefore be expected to encroach on tailings piles from downstream drainages or from established drainages on the impoundments.

Horton overland flow begins at a critical distance from slope crests or inflection points in the profile. The critical distance is that at which the hydraulic power of the flow exceeds the strength of the soil and vegetation to resist particle movement. The greatest erosive force from this type of overland flow occurs at the inflection point between convex/upward and concave/ upward slopes. Horton overland flow can initiate gullies separate from established drainage systems.

Major factors influencing gully formation are topographical features such as slope angle and slope length, the existence of stable base levels on or near the site, the erodibility of the soil, and the flow velocity. Specific geomorphic and hydrologic conditions that increase the potential for gullying include steep slopes, narrow flow width, and large run-off volume relative to the drainage area. Site-specific information is necessary to determine the potential for gully formation. 
Flood Intrusion

Tailings piles located on flood plains of rivers could experience erosion stress resulting from flood water. Factors affecting the potential for flood intrusion are the hydrologic and hydraulic characteristics of the river systems. The stability of a tailings pile during a flood is primarily influenced by the quantities and flow velocities of the flood water in the immediate vicinity of the site. These factors depend, in turn, on the location of the impoundment within the flood plain and the magnitude of the flood.

Flood protection methods have been developed around concepts of initiating movement in single particles. A brief summary of those concepts is therefore presented in this section. The dynamics of river systems and their effects on long-term stabilization of tailings piles are presented in the next section. Most of the theory is derived from sediment transport research based on laboratory and field observations.

Water flow over a layer of particles initiates movement when it approaches a velocity sufficient to momentarily entrain individual particles. The entrained particles generally bounce back and forth without net displacement. A slight increase in velocity removes some particles and destroys the integrity of the layer. Initiation of movement is not simultaneous across a given particle layer of uniform size. Movement within a uniform layer is intermittent because of turbulent water flow.

The forces acting on a particle under flowing water are gravity, $1 \mathrm{ift}$, and drag. Under critical or threshold conditions, the hydrodynamic forces acting on a particle are balanced by resisting forces. When in this balanced condition, the particle is considered to be at the point of incipient motion.

Three basic approaches have been used to mathematically describe the initiation of particle motion (walters 1982). The first is the critical velocity approach, which considers the force balance of a particle where the flow velocity generates both a lift and a drag force. The second is the critical shear stress approach, which considers the force balance on a water column and the resulting shear force on the particle. The third is the lift force mechanism, which involves a pressure difference caused by the steep velocity gradient near 
the particle, together with upward velocity components resulting from turbulence. Walters considers the critical shear stress approach to be the most useful for designing flood protection for tailings piles.

Settlement and Mass Wasting

Mass wasting is the downslope movement, en masse, of soil or rock in response to gravity. The movement can range from slow (creep) to rapid (debris avalanches). On tailings piles, mass wasting is most likely to result from differential settlement of the tailings or failure of the cover material on the steeper slopes of the impoundment. Slope failure could directly expose tailings or damage the radon barrier. The types of mass wasting possible in the cover material are slumps and earth flows that are related to piezometric conditions in the earthen cover (Zellmer 1981). Cover systems that tend to confine water movement into a saturated zone (e.g., those using asphalt or relatively impermeable clay as radon barriers) would be most susceptible to mass wasting.

\section{BIOTIC INTRUSION}

Plant and animal activity in and on covered tailings can affect the stability of the impoundment and the performance of the containment system. Biological factors other than those resulting from human activity are prinarily long-term problems because the establishment and development of plant and animal communities are relatively slow. For this reason, the consequences of biotic intrusion on uranium mill tailings containment systems have been largely ignored by researchers and government agencies.

The largest body of evidence supporting the significance of biotic intrusion comes from research on low-level radioactive waste. Initially, biological factors were thought to be a minor problem. As investigations of low-level waste burial sites were conducted, however, the effects of biological factors, especially over the long term, became more apparent (McKenzie et al. 1982). While not all of the biological factors important to low-level waste are relevant to uranium mill tailings, an appreciation of the processes and concepts is useful for designing containment systems intended to function for hundreds of years. 
Mechanisms of Contaminant Escape

Biota may be involved in contaminant escape through transport enhancement, active transport, and secondary transport. Biota can increase the probability of contaminant escape by altering the cover system. Burrowing of animals and penetration of plant roots in the soil cover result in a series of tunnels and chambers that may promote the escape of radon gas (Wullstein 1978; McKenzie et al. 1982). As an indication of how extensive burrowing can be, approximately two miles of pocket gopher tunnels were estimated over a low-level waste burial site at Los Alamos National Laboratory (Hakonson, Martinez, and White 1982). Vogel, Ellington, and Kilgore (1973) reported that prairie dogs construct their mounds in a way that promotes wind-induced ventilation through their tunnels. Tunnel volumes for harvester ant colonies averaged $1774 \mathrm{~cm}^{3}$ per colony on low-level waste burial grounds at Hanford, Washington, with up to 358 colonies per burial ground (Fitzner et al. 1979). Channels created by animals and plants may also promote the infiltration of surface water into tailings. Burrowing animals increase erosion of cover materials by bringing soil to the surface (Winsor and Whicker 1980).

Active transport is the process considered to be most significant in contaminant transport from buried waste. Plant roots penetrate into waste and translocate toxic elements through the roots and stems to the above-ground plant parts. Plant uptake of radionuclides and other toxic chemical elements from uranium tailings may constitute a significant transport mechanism (Yamamoto 1982). While the necessary information regarding plant uptake on covered tailings piles is incomplete, the possible hazards should be considered when designing protective covers. Special attention should be given to transport over periods longer than 100 years.

Burrowing animals may actively transport waste by physically moving contaminated material, by contaminating their bodies externally and redistributing contaminated material in their day-to-day movements, and by ingesting contaminants and spreading them in feces or, ultimately, in their carcasses. Probably the most important active transport method that affects uranium mill tailings piles is the physical movement of materials. Both ants and small mamals tend to prefer disturbed areas for burrowing (Fitzner et a1. 1979). The amount of 
material moved to the surface varies with species and site, but may be significant; for example, $155 \mathrm{~kg} / \mathrm{ha} /$ month has been reported at one low-level waste site (Winsor and Whicker 1980). So il movement by harvester ants on low-level waste sites at Hanford, Washington, was estimated to average about $1 \mathrm{~kg}$ per colony per year (Fitzner et al. 1979). The authors (Beedlow and Hartley) have observed that uranium tailings were redistributed through radon barriers by ants and prairie dogs on the Grand Junction tailing pile. At moist sites, earthwoms may constitute a significant transport mechanism, al though little work has been done on their ability to transport wastes.

Once the contaminated material has escaped the containment system, secondary transport mechanisms can be responsible for further mobilization. Leached material that returns to the surface can enter the food chain through biotic transport. Contaminated plant material may be transported by wind or ingestion by animals.

Factors Affecting Root Depth and Animal Burrowing

The rooting depth of plants is somewhat species-specific; however, environmental factors greatly influence actual rooting depth. Soil properties including nutrient content, aeration, moisture, osmotic pressure, temperature, pathogen content, pore size, and compaction affect root penetration (Brady 1974). Plant life-form is related to rooting characteristics (Grime 1979). Grasses tend to have fibrous roots systems that are relatively shallow. Taprooted plants such as trees, shrubs, and forbs tend to grow deeper.

Soil type can affect rooting depth. In general, loamy soils allow the greatest root development, while clay and sandy soils tend to restrict growth (Brady 1974). However, wild plants can adapt to adverse soil; for example, roots of invading weeds (Salsola kali and Kochia americana) were observed at all depths in the adobe cover at the Grand Junction test site (Beedlow, McShane, and Cadwell 1982).

Vegetation type and soil properties affect the species of burrowing animals in an area (McCloskey 1976; Price 1978; 0'Farrell 1980). Most burrowing mammals prefer open vegetation; tall dense grass tends to discourage them. Soil texture is an other important factor, the requirements varying from 
species to species. Burrowing depth of many hibernating rodents seems to be influenced by the average depth of frost. Information on factors affecting habitat selection and maximum recorded burrowing depths for those small mammals that are considered most likely to inhabit waste burial sites in the West is summarized by Gano and States (1982).

Thin rock covers used in conjunction with vegetation to control erosion are likely to alter soil characteristics, such as texture and amount of rock, that can affect the species composition and structure of vegetation (Douglas 1972; Barbour and Diaz 1973; Harner and Harper 1976). Plant traits that could be affected include size, vigor, woodiness, root depth, reproduction and seed germination, and susceptibility to stress. In general, rock placed on the soil surface in a manner similar to that proposed for protective covers was found to increase the weed, shrub and forb cover and decrease the grass cover at a field test site in northern New Mexico (Beedlow and Carlile 1984).

\section{SOIL MOISTURE}

Uranium mill tailings usually occupy an unsaturated flow zone constituting the transition region between the atmosphere and a groundwater system. An unsaturated flow zone gains moisture from precipitation, agricultural irrigation, and seepage from rivers and lakes. Moisture is lost by evaporation, plant transpiration, and drainage. Soil moisture moves in an unsaturated zone under the influences of gravity, Darcian flow, and vapor diffusion. Gravity causes downward movement of soil water until the restraining force due to capillary hydraulic potential (natric potential) is in balance with the gravity force. If the capillary action is stronger than the gravity force, upward moisture movement may occur.

Movement of soil moisture by vapor diffusion is significant near the soil surface and is the primary mechanism controlling moisture loss by surface evaporation. Potential evaporation rates are the highest when the soil near the surface is nearly saturated; a dry layer of soil limits evaporation.

If the water infiltrating the soil profile exceeds the capability of the soil to store it, drainage will occur. This drainage may enter the groundwater system, depending on the depth of the water table. Soil layers of clay, silt, 
sand, and gravel affect the movement of soil water differently. Certain layers rapidly transmit soil moisture, while others impede its movement.

Except in cases where the groundwater level lies within the tailings, soil moisture dynamics are driven by input from precipitation and regulated by surface conditions. Expected surface conditions on tailings range from a cover where vegetation is predominant, to rock/vegetation combinations, to a cover of total rock. At most western sites, where potential evapotranspiration equals or exceeds precipitation, no appreciable accumulation of moisture in the soil/ tailings profile is expected. Normally, evaporation from the soil surface and transpiration by plants removes the water that enters the soil as precipitation. Rock covers generally increase infiltration and decrease evaporation (Mayer, Beedlow, and Cadwell 1981; Kirkham, Beedlow, and Gee 1982). Thus, areas covered with rock can effectively capture more precipitation than adjacent areas without rocks. Thick rock covers are capable of excluding plant growth for a number of years and can cause water to accumulate in, and percolate through, the tailings cover system. Thin rock covers (rock mulches) can promote plant growth. Additional moisture from increased infiltration and decreased evaporation becomes available to plants, supporting more vigorous vegetative cover than would otherwise thrive. Transpiration by vegetation growing in a rock cover can prevent water accumulation if enough vegetation is present. The type of surface cover, then, will affect the moisture balance of the containment system.

GEOMORPHIC CONSIDERATIONS

In order to assess the long-term stability of a uranium mill tailings containment system the geomorphic processes that could influence the disposal site, including $c 1$ inate change, tectonic activity, base level change, and vegetation and land forin change by man, must be considered. These processes affect the land form in the area surrounding the disposal site, and a change in any or all could create geomorphic hazards as a result of their influence on run-off, sediment yields, river behavior and slope erosion. A geomorphic hazard is defined by Schumm et a1. (1982) as "any landform change, natural or otherwise, that may adversely affect the geomorphic stability of a disposal site." These 
changes occur very slowly and are only considered a hazard in that after a very long time (thousands of years) their cumulative effect may threaten the stability of the disposal site.

The site should be located on a relatively stable geomorphic surface. However, for the site inactive tailings piles, remedial action plans must be developed to meet site conditions (environmental setting, climate regime, bedrock type, rate of change, etc.). For each site, potential changes in hillslope erosion rates and accompanying stream behavior must be evaluated against potential changes in climate, base level, and tectonic activity.

Uranium mill tailings sites are generally located within a fluvial system (land form complex), as shown in Figure 2. The fluvial system is divided into three simplistic zones (Schumm et a1. 1982) that are hard to distinguish from each other: 1) the drainage basin (a sediment and run-off zone), 2) the major streams and valleys (a sediment and water transport zone), and 3) the piedmont or coastal plain (a depositional zone). These zones adjust to climate change, tectonic effects, and base level changes by altering sediment deposition and storage in Zones 1 and 2 and erosion in Zone 3. Significant variables influencing the fluvial system in relation to land form stability are: 1) time-natural land form evolution; 2) relief--change of relief as a result of tectonics (uplift or down-warping) and base level change; and 3) climate change--change of vegetation and hydrologic regime. These variables will affect run-off (discharge), sediment load, and base levels. Schumm et al. (1982) also describe the relative effects of climate, tectonics, and man upon discharge, sediment load, and base level.

If the required geomorphic, climate, tectonic and hydrologic data are not available for the tailings disposal site, a geomorphic evaluation of the site is necessary.

Geomorphic Hazards

In order to evaluate the geomorphic stability of a uranium tailings disposal site, the present and potential geomorphic hazards must be identified. As previously defined, a geomorphic hazard is any land form change, natural or man-made, that adversely affects a disposal site. 


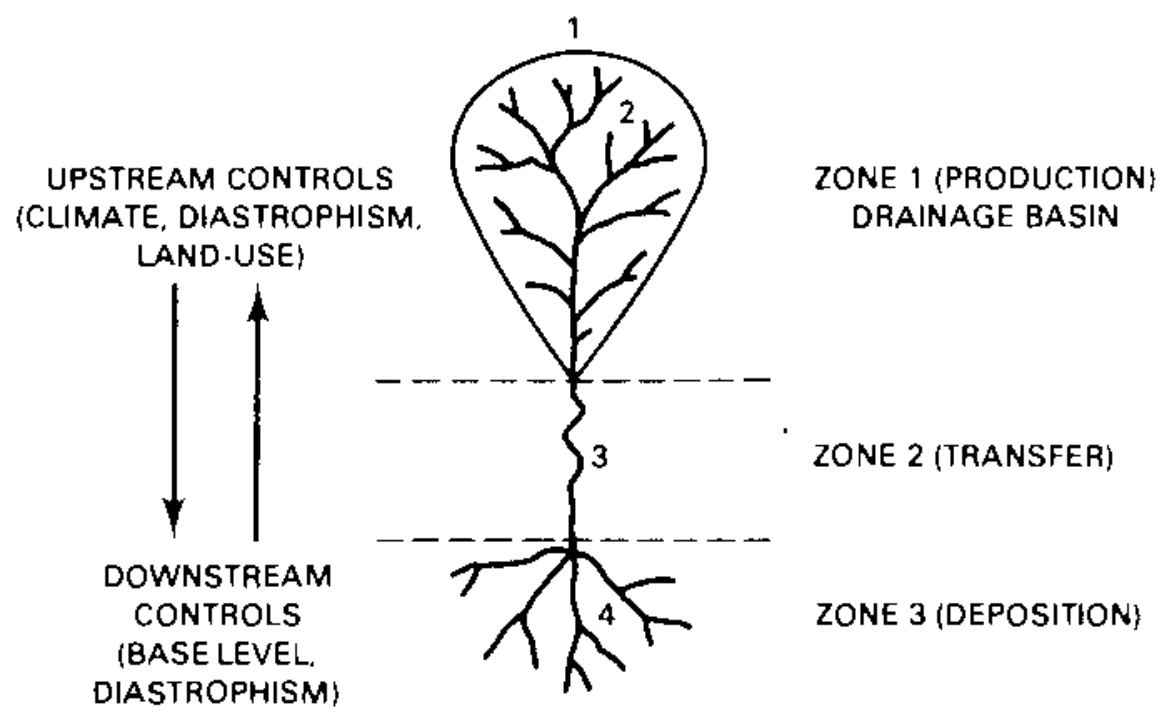

FIGURE 2. The Fluvial System (after Schumm and Chorley 1983)

Twenty-eight geomorphic hazards that occur as a result of climate, tectonic, or base level influences have been identified by Schumm and chorley (1983). They are grouped by location within the fluvial system (Figure 2) and by process; most are process-related. The major hazards are summarized below:

- Drainage networks

- erosion (rejuvenation)

- deposition (valley filling)

- pattern change

- Slopes

- erosion

- Rivers

- erosion

- deposition

- pattern change

- metamorphosis.

The majority of the inactive tailings sites are located on or near major land forms of the fluvial system. In evaluating the stability of these sites, the long- and short-term rates of fluvial processes must be detemined for each site. This involves 1) quaternary stratigraphy, 2) radiocarbon and/ or cultural dating, and 3) landscape reconstructions (i.e., inference from 
paleotopography). Examples of these procedures and results are summarized by Wells and Jeranovic (1983). These studies show, for example, that the valley floors of fluvial systems in northwestern New Mexico have experienced an aggradation over the past 1000 years that could influence the position of streams and increase the potential for flooding any nearby tailings areas.

Radiocarbon dating of, for example, a buried tree can be used to determine whether the area selected for disposal has had recent vertical aggradation. Channel incision and bank erosion have a dramatic effect on the short-term geomorphic stability. Current research (Duffy and Gardner 1983; Mill and Gardner 1983; Wells and Jeranovic 1983) incorporates techniques of quantifying historic rates of change in the fluvial systems: 1) repetitive aerial photography, 2) erosion grids and pins, and 3) measuring cross-sectional and longitudinal profiles.

Estimating the rates of these geomorphic processes will help to determine the stability of the tailings disposal site as well as provide criteria for designing the containment system. The information and data needed for this geomorphic site assessment are summarized by Schumm et a1. (1982) and Schumm and Chorley (1983) and include 1) aerial photographs and topographic maps of site and surrounding area, 2) regional information on climate, hydrology, vegetation type and density, and geologic maps and reports, and 3) geology and geomorphology (stream, hill slope, and drainage network morphology). Much of the geomorphic information will have to be obtained from field investigations. A detailed review of ways to assess the geomorphic stability of a disposal site is presented by Schumm and Chorley (1983).

Impact of Geomorphic Change on Flood and Gully Intrusion

The long-term stability of a tailings pile will be affected by the potential for flood intrusion onto the tailings impoundment and for extension of offsite gullies into the impoundment area. It is necessary to evaluate proposed remedial action designs to ensure that geomorphic processes that could cause instability do not threaten the design. Protection against flood and gully intrusion must be part of the remedial action design. 
River Channel Morphology

The geomorphic stability of existing rivers must be determined and appropriate remedial action designs developed. If the tailings pile is on the flood plain or a low terrace, potential river shift could lead to direct river intrusion on the site, increasing the flood damage. The rate at which a river meanders across a flood plain is generally slow compared to other geomorphologic events, but river shifts may occur several times during the period of interest for long-term stability (Nelson et al. 1983). It is therefore necessary to consider the possibility of river shift when developing remedial action plans. A number of reports describe the morphology and dynamics of rivers (Gregory 1977; Morisawa 1968; Schumm 1977; Simmons and Sentuck 1977).

The behavior of a river depends not only on the stability of a particular river reach, but also on the behavior of the fluvial system of which it is a part. Rivers are complex land forms and a simple and straightforward approach to the identification of river hazards is not always possible. Although detailed studies may indicate that a particular site is stable, upstream and downstream changes may affect the future stability of the site.

Rapid and unexpected river changes may occur because of natural or manmade disturbances of the fluvial system. It is therefore important to be able to predict changes in channel morphology, location, and behavior. Schumm and Chorley (1983) discuss channel behavior and potential hazards, and recommend methods of field investigation to evaluate river stability that include reconnaissance, field inspection, and historical study.

Based on the work of Schumm and Chorley (1983), the primary concern with river intrusion appears to be lateral movement of the stream channel, causing undermining or erosion of the tailings impoundment. Because of the forces associated with flood events it is difficult to construct remedial measures that will adequately protect the impoundment against intrusion by major rivers. If there is evidence of historical river shift at the tailings pile or at locations upstream or downstream from the site, potential impacts of channel shift must be carefully evaluated according to the available geomorphic evidence. 
At sites where river channel shift is not expected to affect the site but where some flood waters may come into contact with the impoundment, slope protection measures such as those discussed previously are necessary. Under such conditions, it may also be necessary to consider a height of protected slope greater than that required to protect against the PMF, because of the additional height of potential wave run-up. Analysis techniques and computational methods for predicting flood intrusion have been described by Nelson et al. (1983). Computer codes are available to define the flood plain (1imits and characteristics). For complex river systems, physical hydraulic models are a) so used.

\section{Gully Migration}

Gullying potential in the area surrounding the site has been discussed. Consideration should be given to the potential for geomorphic changes to cause gully migration into the impoundment drainage area.

Guliy migration is dependent on existing site conditions, the percentage of total drainage area already gullied, and future land use changes by man. Headward migration may also be caused by such factors as uplift and base leve 1 changes. Since geomorphic considerations beyond a 100-year period cannot include or forecast future land use changes, it is concluded that design considerations regarding potential gully extension or migration must be based on existing conditions and future changes that can be predicted using present knowl edge (Nelson et al. 1983).

Gully intrusion will not occur if stable base levels exist and if surrounding slopes are sufficiently flat so as to be below threshold values. Because gully intrusion may disrupt the pile even in short time periods, adequate protective measures must be provided to prevent gully initiation. If gully intrusion is prevented even for the short term, stability for long-term periods (up to 1000 years) can be expected as long as sufficiently durable material is used. 


\section{ENGINEERING STABILITY}

Tailings consist of sand-, silt-, and clay-sized particles distributed in a stratified, nonhomogeneous manner (Wong, Wardwell, and Van $Z y 1$ 1984). As tailings are slurried into impoundments, the sands tend to deposit near the outlet while the slimes are carried inward. The high variability in tailings properties resulting from nonuniform deposition affects the stability of the pile upon reclamation.

Sand and slime zones settle unequally as the tailings consolidate (Nelson et a1. 1983). Initially, consolidation results from dissipation of excess pore water pressure. Secondary consolidation is due to volumetric strain related to the viscous resistance of the tailings. Settlement can be initiated by the weight of the tailings material, or by the weight of the protective cover. Settlement may also occur because of consolidation of the underlying soils.

Differential settlement of the slimes and sands areas can damage the protective cover. Cracking can lead to gully formation. Localized depressions can impound water, causing excess water to enter the tailings and increase radon release. Deformation of the cover can channelize run-off, resulting in localized erosion.

Prediction and mitigation of differential settlement are discussed by Nelson et al. (1983). Prediction is based on standard engineering techniques using material properties and stress analysis. Common engineering methods such as surcharging and surface grading are suggested to mitigate adverse effects of differential settlement. The use of sandy materials that are self-healing would minimize cracking of the protective cover. 


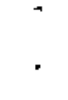

.. 


\section{AN APPRDACH TO DESIGNING SURFACE COVERS}

The wide range of site conditions and availability of cover materials complicates the design of appropriate surface covers. At each site, environmental conditions must be considered in conjunction with the characteristics of the tailings pile and the availability of materials. As a basis for design planning, a decision tree is presented in Figure 3. The tree outlines the process of gathering site information necessary for designing a protective cover and for evaluating its effects on the containment system.

The decision tree shows the process of designing protective covers in three phases: The first, or assessment phase, involves collecting the appropriate site information in order to construct a preliminary plan for the protective cover (Phase II). The preliminary plan describes the general characteristics and presents alternatives. The plan is used in conjunction with preliminary designs of the other components of the containment system to produce a conceptual site design. After a conceptual design has been formulated, Phase III begins. During Phase III, optimization results in a detailed site-specific surface cover design. The detailed design is evaluated with respect to the entire containment system to produce a finalized design. A brief discussion of the steps involved will illustrate the procedure.

Phase I involves collecting the necessary data and evaluating site conditions so that a preliminary plan for the protective cover can be formulated. Initially, the required data must be gathered from existing reports and from site visits. The general types of data should include:

- topographic maps showing the pile location and the upstream and downstream drainage area

- drawings and photographs of important features of the tailings pile, such as sectional drawings of material zoning and foundation stratification, and top and bottom elevation profiles

- foundation data and geological features from boring logs, geological maps, profiles, and cross sections

- physical and chemical properties of the tajlings 


\section{PHASE :} ASSESSMENT

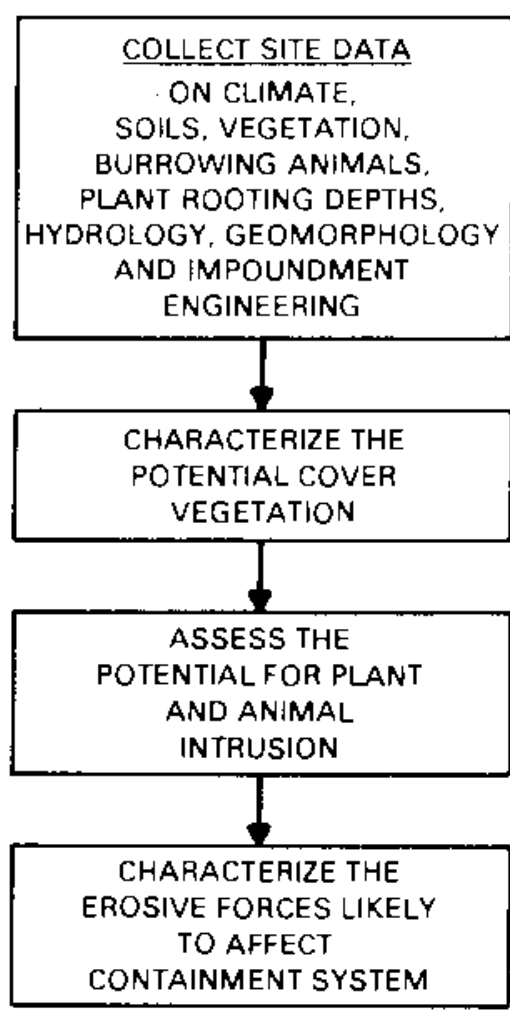

* PROtective cover INFormation CONTRIBUTES TO ANALYSIS OF ENTIRE CONTAINMENT SYSTEM
PHASE II: PRELIMINARY DESIGN

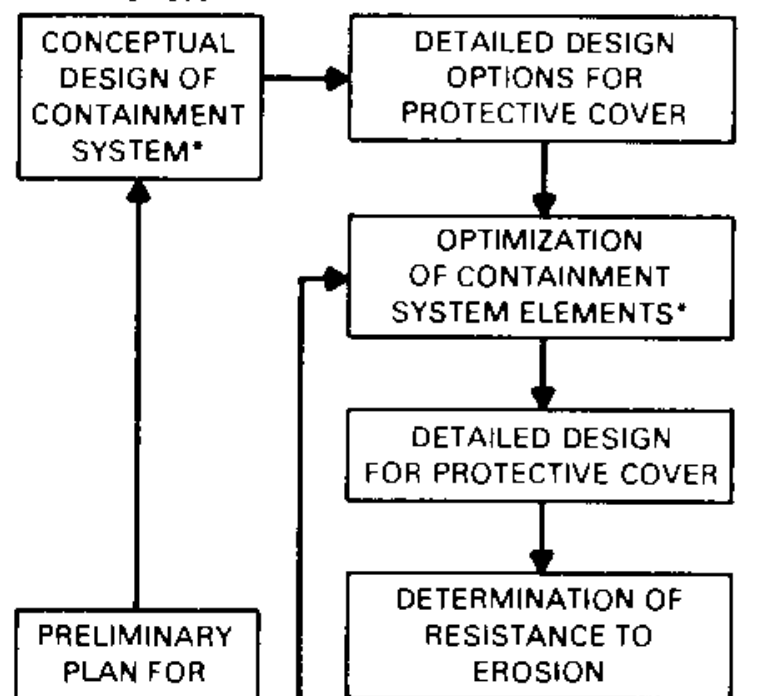
COVEA

\section{FIGURE 3. Decision Tree for Designing Protective Covers}

for Inactive Mill Tailings 
effective in reducing erosion, but they may not be locally available. The cost of using rock covers is heavily dependent on the distance the rock must be hauled. At some distance rock may no longer be affordable.

If rock cover is feasible, a preliminary plan using rock or rock/vegetation covers can be produced. If suitable rock is not available, the use of additional overburden, greater amounts or better quality topsoil, or the recontouring of the pile may reduce erosions rates; once these options are determined, erosion potential is recalculated. This process may require several iterations before a preliminary plan is produced.

The preliminary plan for the protective cover is intended to provide information and alternatives for planning other elements of the containment system, and to adapt the protective cover to the overall plan. Once the overall containment system concept has been approved, Phase III begins.

In the third phase of the design process, the available options for protection at the site are determined in some detail. The cost and effectiveness of the alternatives are optimized in conjunction with other containment system components. Before the final design can be chosen, effects of the protective cover on the functioning of the entire system must be evaluated. Erosion rates are determined using site environmental data and engineering specifications. Effects of surface covers on soil moisture should take radon and biological barrier designs (and liners, when appropriate) into account. The risk and possible effects of biointrusion caused by the proposed surface cover must be evaluated at this time. If the consequences of the protective cover design do not jeopardize the functioning of the system based on the above evaluations, the design can be finalized. If the surface cover does jeopardize the functioning of the system, then alternative designs are considered. Several iterations of this process may be necessary.

The major benefit of the decision tree approach is the flexibility it allows. It does not specify types and amounts of cover material but requires only that designs provide adequate surface erosion control and containment of toxic compounds. Adequate erosion control is, logically, that required to keep 
- drainage area and basin characteristics, including soils, vegetation, and geomorphological features

- data on flood histories and on discharges from all watercourses

- climatic data for calculating erosive forces

- availability, quality, and costs of soil, rock, and plant materials

- information on animal burrowing and human activity in the vicinity

- site geomorphologic assessment.

The potential cover vegetation can be estimated by evaluating the existing vegetation on soils that are available for use as cover material. Careful examination should be made of the chemical and physical properties of candidate soils throughout their profiles. Because of mixing, soils that are excavated may possess different characteristics when placed on a tailings pile. Eventually, where soils and topography are similar, vegetation on the covered tailings can be expected to resemble that in the surrounding area.

The potential for plant and animal intrusion can be detemined from survey data in conjunction with published information. Important characteristics include rooting and burrowing depth, animal and burrow size, ability to incorporate hazardous materials into tissues, propensity for growing or burrowing in disturbed soils. An assessinent of human intrusion potential can be made by characterizing human activities in the area. Site data on vegetation, climate, soils and geomorphology can then be used to detemine the erosive forces acting on the pile. Areas exposed to stream flooding may need riprap or other forms of engineered armor. Those not exposed to flooding can be adequately stabilized by vegetation and/or unengineered rock covers. Based on the calculated erosion rates and criteria for stability, the adequacy of vegetation for surface protection should be determined, because even if no surface treatment is applied, vegetation will become established in time. If vegetation is considered adequate, a preliminary revegetation plan is produced. If vegetation is judged to be inadequate for long-term erosion control on all or parts of the pile, other means must be used to prevent erosion damage. The need for and cost of suitable rock for covering the entire pile or portions of pile exposed to high erosion rates must be determined. Some types of rock can be very 
the protective layer intact for the design life of the containment system. A surface cover, therefore, can be any combination of soil, rock, and vegetation that is effective and economical. 
: 


\section{DESIGN TOOLS AND CONCEPTS}

A single tailings pile could conceivably require several different types of protective covers depending on the expected erosive forces, biotic intrusion potential, and soil moisture dynamics. Sloped areas that are subject to higher erosion rates may require different treatments from those that are level. Where stream erosion is expected, relatively massive rock riprap may be required. Portions of the tailings above the projected flood level will require protection from wind and overland flow. Plant and animal intrusion potential will vary from site to site and from place to place on a single pile. Soil moisture requirements and designs to control infiltration will depend on the type of radon barrier and the surface cover.

Al though each site will be designed individually, basic protective cover designs are presented. These are intended to familiarize the reader with designs that have been used in current research efforts, and to inform design engineers of the components necessary for maximum effectiveness of protective covers.

\section{BASIC DESIGNS FOR PROTECTIVE COVERS}

Erosion protection requirements will vary according to expected erosion stresses. The degree of protection ranges from that provided by established vegetation to that of heavy-duty rock riprap, as shown in Figure 4. Rock riprap is placed on the slopes and around the base of the impoundment to prevent flood damage and gully encroachment. Riprap is also used on slopes that are susceptible to gullying from impoundment run-off. Piles or portions of piles not exposed to flooding or gully development will not need this much protection. Where riprap is used, filter layers are necessary to provide a stable base.

Slopes greater than approximately $10 \%$ are particularly vulnerable to erosion. Stabilizing these slopes is critical in preventing both wind and water damage to the entire pile. Slopes above the design flood level may be protected by light-duty rock riprap consisting of gravel and cobble-sized material (Figure 4). 


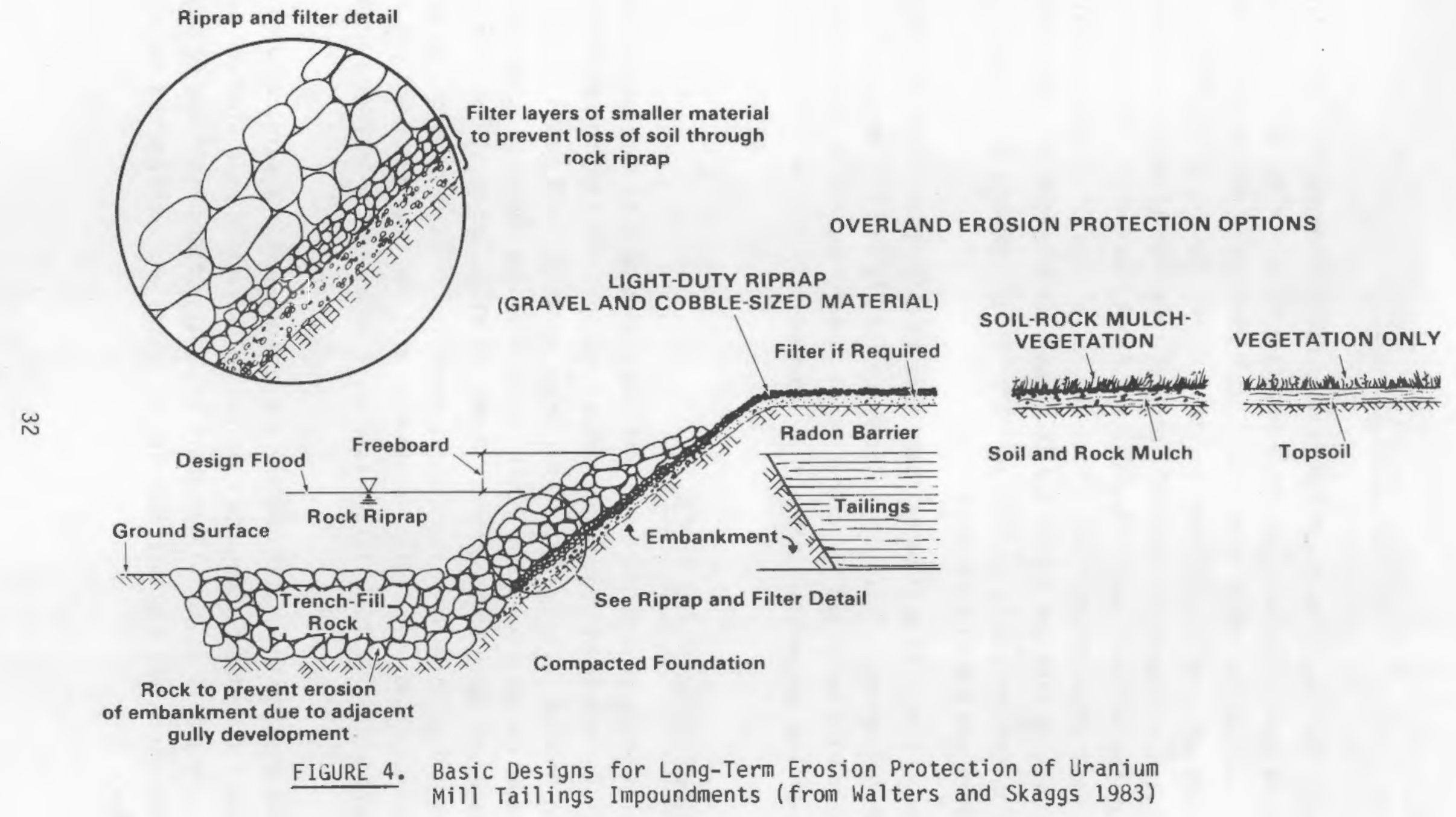


On flat and gently sloped ( $<10 \%)$ portions of the tailings pile, vegetation, a combination of vegetation and surface rock (rock mulch), or rocky soil can be used. The potential vegetative cover at a particular site should provide the criteria for determining the composition of the surface cover. For example, rock mulch should be used at sites that are not likely to support enough vegetation to stabilize the soil. Alternatively, the formation of rock pavements may be encouraged by placing soil material containing properly graded stones.

Vegetation should be established at all sites even if the expected cover will provide sufficient erosion protection. Vegetation will prevent the accumulation of excess soil moisture when rock covers are used for stabilization. Alternatively, the rock covers can be engineered to drain laterally; these must remain functional for the design life of the impoundment. Such engineering, while certainly feasible, is complicated by the need to allow for climate change and, inevitably, vegetation growth that could change the drainage characteristics. A plant community consisting of species adapted to the local environment is dynamic; it is capable of responding to changes in $\mathrm{cli-}$ mate. By increasing and decreasing in response to available soil moisture, vegetation can be an efficient and reliable "pump" for removing excess soil moisture. Mesic areas present a problem in that vegetation alone will probably not be able to remove all of the excess moisture; additional measures such as impermeable layers or drain fields may be necessary.

In the West, establishment of plant species with desirable characteristics can prevent the invasion of unwanted species. Desirable plants are those that have shallow root systems, are unpalatable to grazers, and are persistent with respect to fire and climate change. Most invading or "weedy" species lack these qualities, and are generally undesirable. In arid and semiarid areas, undesirable species can be preempted by establishing perennial or persistent species. At mesic sites, such as those in Pennsylvania and Texas, active management may be necessary to maintain desirable species. 
Establishing vegetation may be desirable for aesthetic reasons and to lower the risk of human disturbance. Public opinion is strongly against the locating of tailings piles near populated areas such as Salt Lake City, Durango, and Shiprock. Relocation, however is the most expensive form of remedial action, and the difficulty of persuading local residents to accept a tailings impoundment in their area is obvious. If tailings piles can become an unobtrusive part of the landscape, however, they may eventually become more acceptable.

Figure 5 shows three basic cover designs that make use of vegetation. Surface covers of vegetation (Figure 5a) involve seeding selected plant species directly into overburden material or placing soil conducive to plant growth (topsoil) over the overburden and seeding. Under arid conditions, where poor quality soil is used, or on slopes too steep to be protected by vegetation alone, additional protection can be afforded by surface rock (Figure $5 \mathrm{~b}$ ). This design involves applying a thin layer of rock (rock mulch) or rocky soil to the surface. This combination can be applied over topsoil or overburden capable of sustaining vegetation. The rock, however, may affect the types and amount of vegetation that will become established. Where vegetation alone provides adequate protection, except perhaps against a rare but severe storm, and where aesthetic designs are necessary, subsurface rock can provide additional protection (Figure $5 \mathrm{c}$ ). Subsurface rock can also be used when biotic intrusion barriers are needed. Maximal water accumulation can be expected if the rock is placed near the surface because extraction of water by plant roots is 1 imited to the soil above the rock barrier. Any water percolating through the barrier will be either stored or lost in drainage, which can be lateral or through the radon barrier. The amount of draining water will depend on climatic conditions, the properties of the topsoil, and the transpiration rates of the plants.

Two types of biological barriers have been developed for use on uranium mill tailings piles ( $\mathrm{Cl}$ ine et al. 1982). Physical barriers to animal burrowing and root growth consist of cobble placed over the radon barrier. A polymeric carrier/biocide delivery (PCD) system was developed to provide controlled release of a herbicide. A schematic diagram of the physical and chemical barriers is shown in figure 6 . Tests of chemical barriers suggest that they 

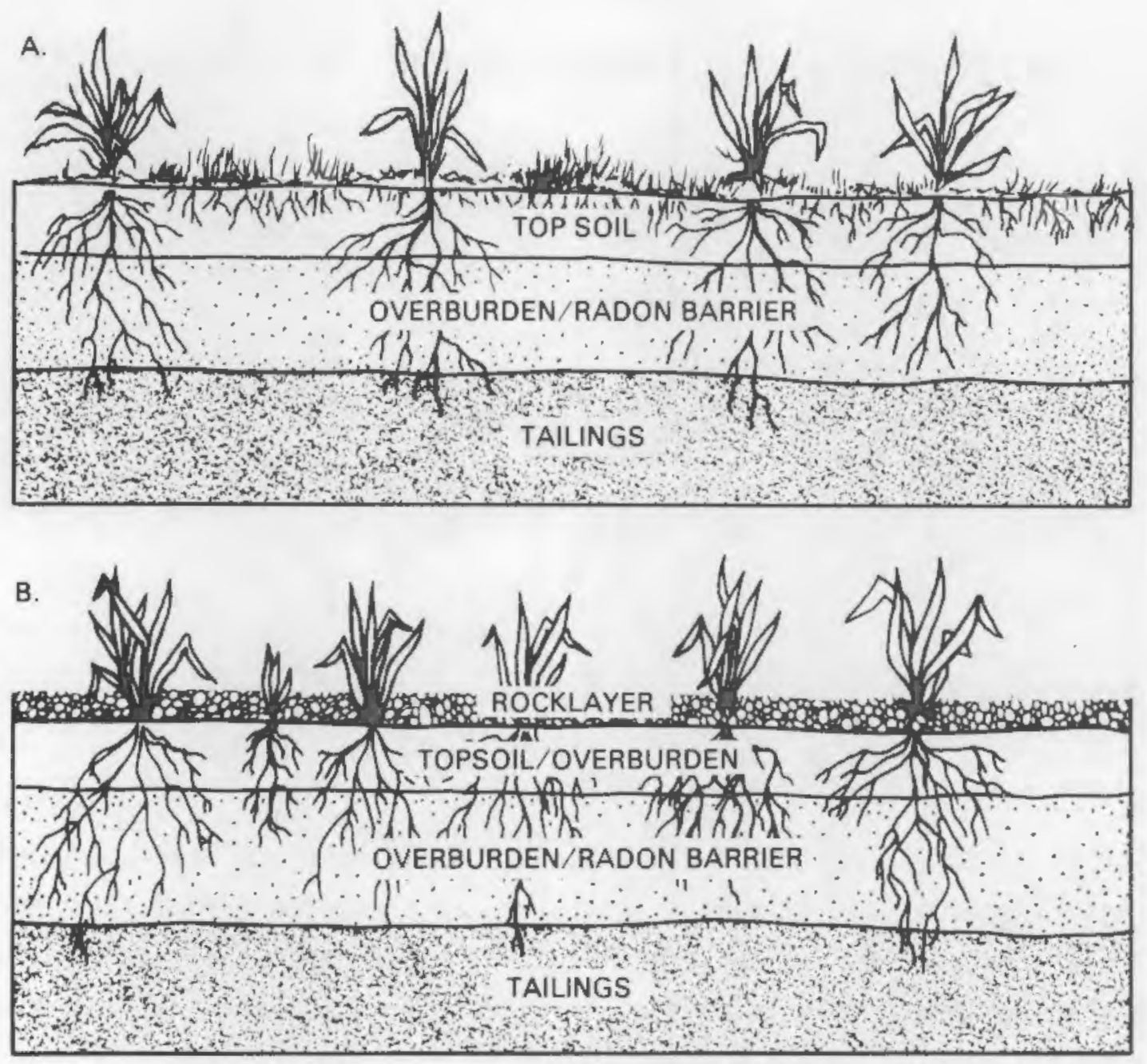

C.

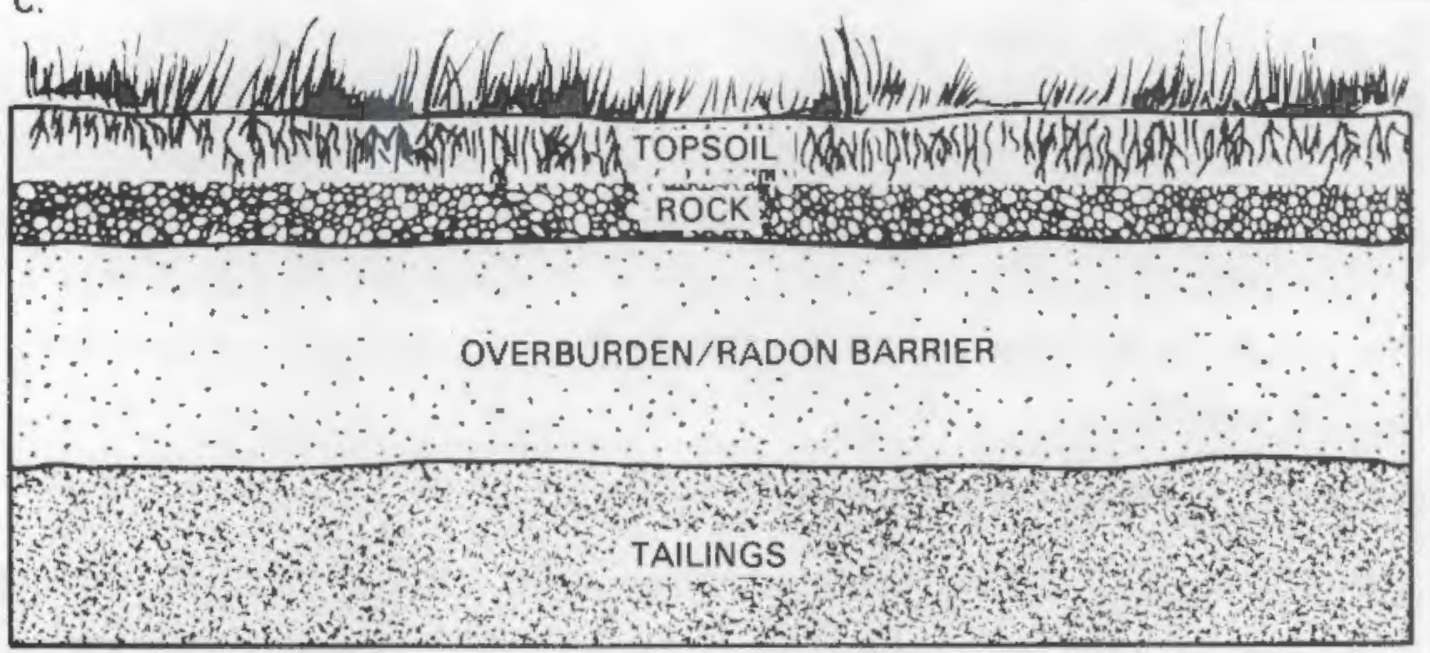

FIGURE 5. Basic Cover Designs Using Vegetation 


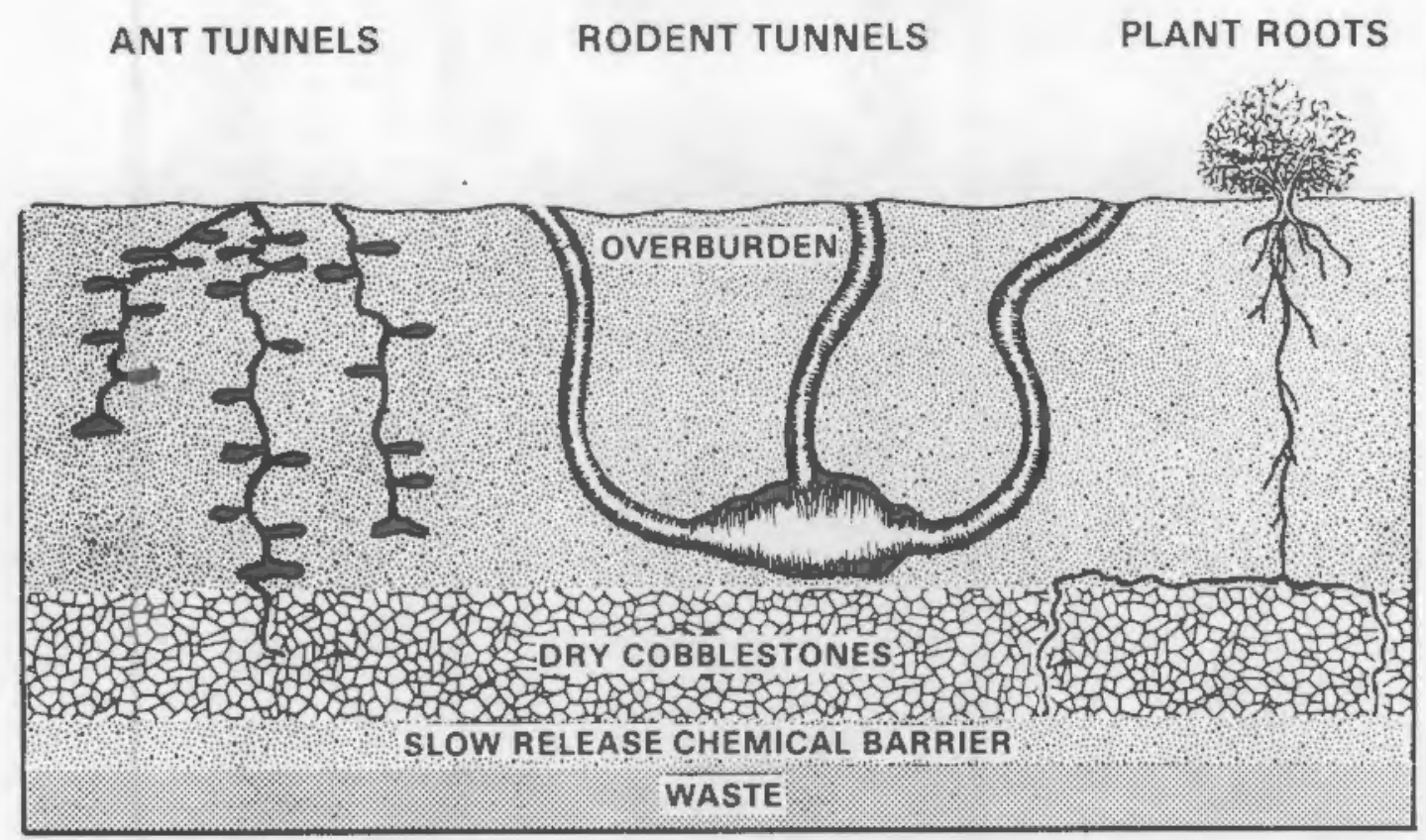

FIGURE 6. Control of Plant and Animal Intrusion

should be effective for 100 to 200 years. Cobble barriers have been shown to be most effective when fine soil particles are prevented from filtering into the spaces between the stones. Cline, Gano, and Rogers (1981) suggest additional guidelines for ensuring the effectiveness of biobarriers: 1) the zone beneath the barrier should be kept as dry as possible; 2) enough soil or other earthen material should be placed above the barrier to hold annual precipitation; and 3) plants should be established, or other means provided, to remove excess water. The guidelines emphasize water control because plants and some animals (such as ants) tend to seek soil water, especially in arid areas. Thus, a zone of relatively high soil moisture in a cover or in the tailings is likely to attract plant roots and animals. The chances of successful exclusion are increased by efforts to ensure that soil moisture does not accumulate below the biotic barrier.

Effectiveness of Vegetation for Erosion Control

Vegetation can effectively control erosion. However, where vegetation is sparse, or under certain erosion stresses (e.g., gully and stream erosion), vegetation may not provide adequate protection for decommissioned uranium mill 
tailings. The use of vegetation for stabilization of tailings in the western United States is of particular concern because the low precipitation and poor soils in many areas often limit vegetation growth.

Assessing the effectiveness of vegetation against erosion is critical to designing long-term protective covers. The wide range in climatic, edaphic, and topographic conditions existing at the various tailings sites requires that surface covers be designed for the particular conditions at each site. In addition, the types of barriers (radon and biological) will affect surface cover design (Beedlow, McShane, and Cadwell 1982). The suitability of vegetation for long-term stabilization of western tailings piles was evaluated (Beedlow and McShane 1984) using the Universal Soil Loss Equation (USLE). The purpose of the study was not to prescribe the use of vegetation, but to determine whether, under the general conditions at western tailings sites, vegetation should be considered part of the surface cover design.

The evaluation (Beedlow and McShane 1984) involved sampling undisturbed soils that are representative of the type likely to be used as the top layer of tailings covers. It was assumed that over long time periods (100 years or more) vegetation growing on the tailings would resemble that existing on similar soil types, as long as the microclimate, slope and aspect of the soil and tailings sites were similar, and the dominant plant species growing on the undisturbed soil were established on the tailings cover. Long-term climatic change was not considered. Site data on soils, climate and vegetation were used to 1) group sites into climatic regions, 2) characterize the vegetation found in those regions, and 3) calculate soil loss by the USLE. No evaluations were made of erosion losses due to wind, gullying or flooding.

The western tailings sites were grouped into three general regions based on climate and geographical location: the Colorado Plateau, the West Slope of the Rocky Mountains, and the Northern Great Plains. Soil loss rates from the Northern Great Plains were the lowest while those from the Colorado Plateau were generally the highest (Figure 7). However, the range of soil loss in each region is quite wide, suggesting that site-specific factors are extremely important. 


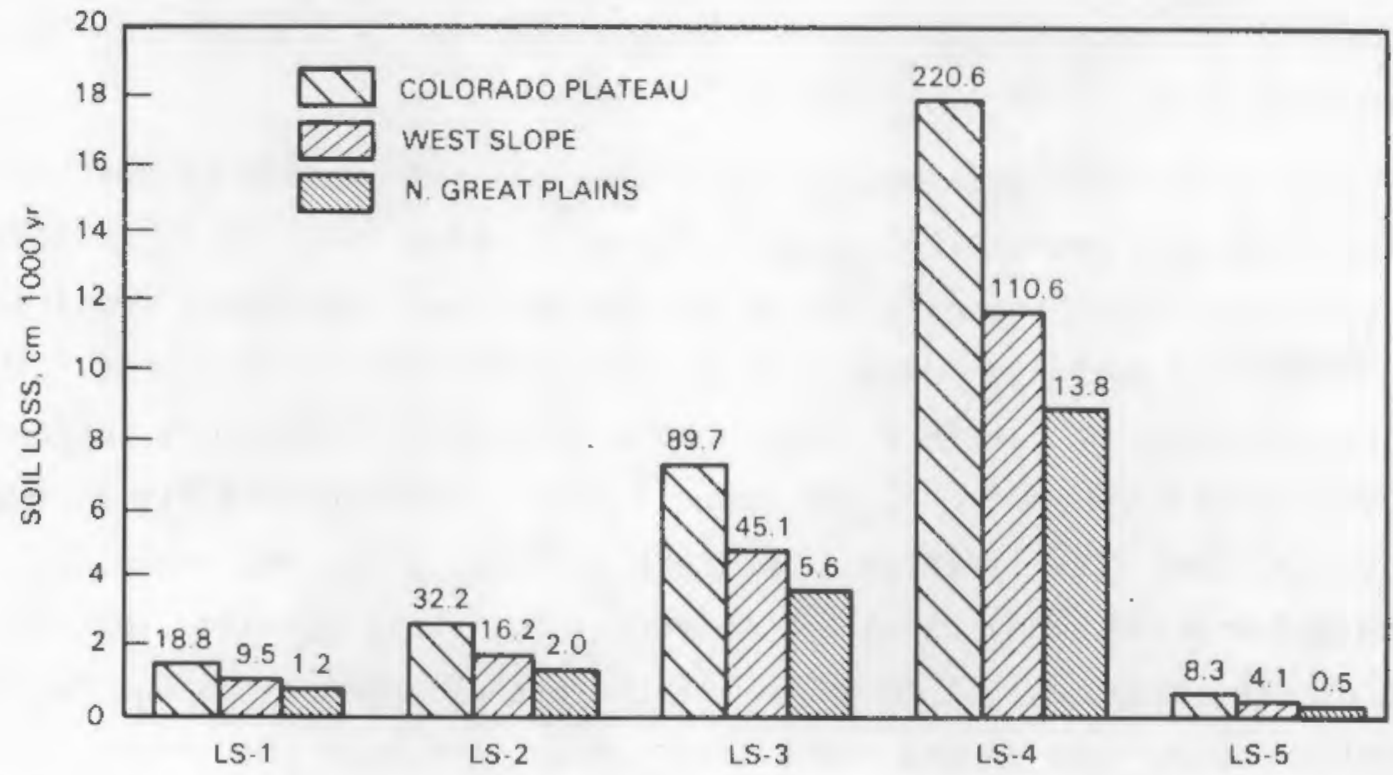

FIGURE 7. USLE Estimates of Soil Loss from Sites Near Inactive Tailings Piles in Three $\mathrm{Cl}$ imatic Regions of the Western United States. Median values are shown, and the range of soil loss rates is shown above each bar. LS-1 $=3 \%$ slope for $30 \mathrm{~m}, \mathrm{LS}-2=3 \%$ for $183 \mathrm{~m}, \mathrm{LS}-3=$ $10 \%$ for $30 \mathrm{~m}, \mathrm{LS}-4=10 \%$ for $183 \mathrm{~m}, \mathrm{LS}-5=2 \%$ for $305 \mathrm{~m}$.

Four major plant community types were identified (Table 1), Grasslands tend to have the lowest soil loss rates while salt shrub areas have the highest (Figure 8). Grass is more effective in stabilizing soil than are canopy plants because it eliminates raindrop impact and reduces the velocity of the run-off (Wischmeier 1972). Shrub communities generally have more grasses in the understory than do salt-shrub regions. Western woodlands of ten have a sparse understory where areas of bare ground are common; for example, the pinyon/juniper woodlands of the Colorado Plateau (e.g., Durango).

Despite the wide range in soil loss rates, the use of vegetation resulted in less than $\sim 30 \mathrm{~cm}$ of soil loss, with median values of $<5 \mathrm{~cm}$, on slopes of $2 \%$ to $3 \%$ (LS-1, LS-2, LS-5) over a 1000-year period. The typical depth of topsoil placed on overburden for revegetation is usually 20 to $35 \mathrm{~cm}$. Over a 1000-year period for low-angle slopes, soil loss due to run-off is not likely to damage the integrity of an impoundment system stabilized with vegetation at any of the sites sampled. Based on this analysis, vegetation should generally be 
TABLE 1. Plant Community Types Identified at Soil Sites in the Vicinity of 20 Uranium Tailings Piles

\begin{tabular}{|c|c|c|c|c|}
\hline Region & Grassland & Shrub & $\begin{array}{l}\text { Salt } \\
\text { Shrub } \\
\end{array}$ & Woodland \\
\hline $\begin{array}{l}\text { Northern Great } \\
\text { Plains }\end{array}$ & $x$ & $x$ & & \\
\hline West Slope & $x$ & $x$ & & $x$ \\
\hline Colorado Plateau & $x$ & $x$ & $x$ & \\
\hline
\end{tabular}

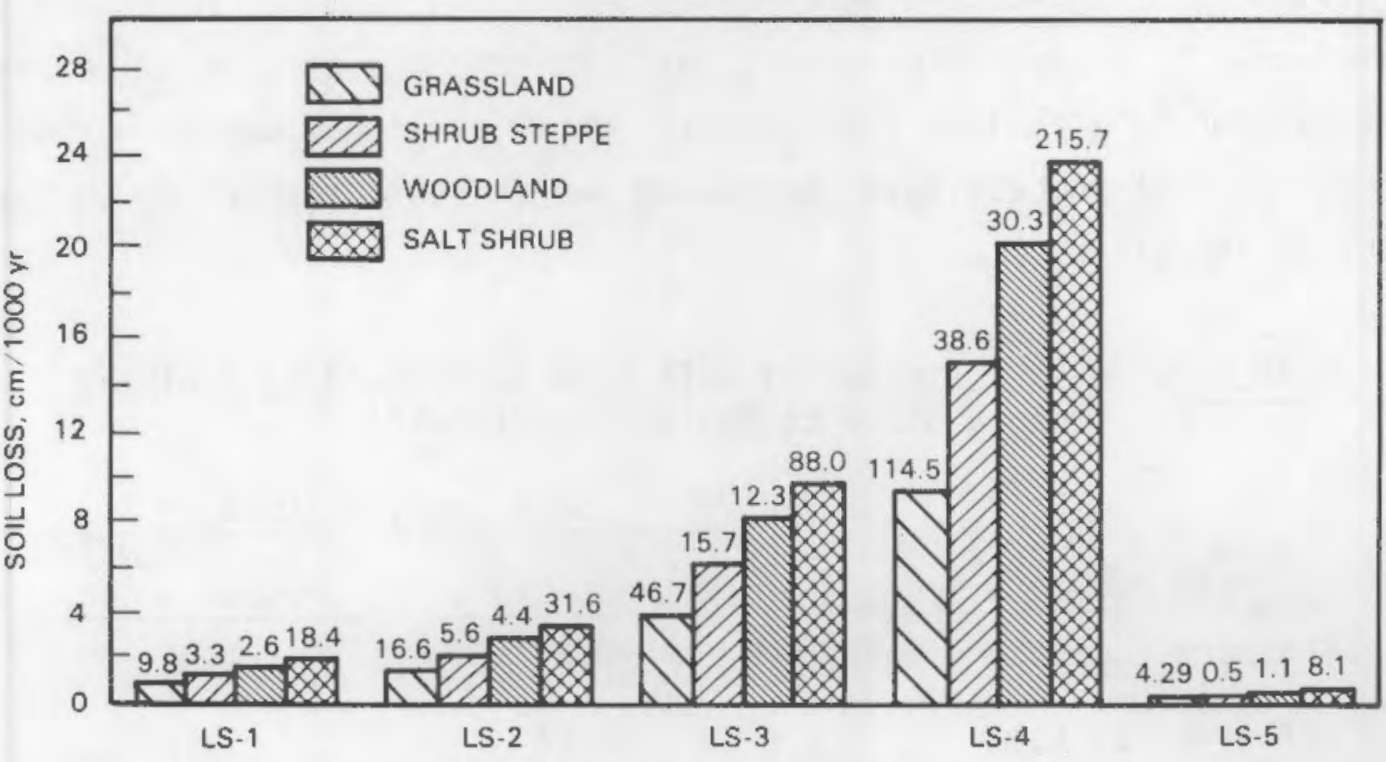

FIGURE 8. USLE Estimates of Soil Loss from Sites Near Inactive Tailings Piles in the Western United States, Comparing Common Vegetation Types. Median values are shown, and the range of soil loss rates is shown above each bar. See Figure 5 for LS values.

considered as a stabilization technique for at least the preliminary surface cover designs. Of course, the final design will require a detailed analysis of all expected erosion stresses. The USLE does not predict erosion caused by gully formation or channel cutting. The detailed evaluations could show that vegetation will not stabilize the surface under particular erosion stresses. 
Soil has been stabilized at construction sites and highway cuts by dumping and spreading crushed stone or gravel over the surface. Table 2 shows the decrease in soil loss by applying 0.64- to $1.27-\mathrm{cm}$-diameter crushed stone at $539 \mathrm{MT} / \mathrm{ha}$ (calculations based on Wischmeier and Smith 1978). The sites shown are those with the highest soil loss rates; a $10 \%$ slope for $30.5 \mathrm{~m}$ (LS-3) is used for comparison. The soil loss rates are drastically reduced because the rock acts as a mulch to eliminate raindrop impact and reduce overland flow. The vegetation in this example was not altered; however, experimental evidence suggests rock-covered soil may support vegetation types different from those with no rock (Beedlow and Carlile 1984).

This exercise suggests that at sites where soil loss may be excessive when protected only by a vegetative cover, surface stone may be used in combination with vegetation to stabilize the surface. Other erosion factors such as flooding or gullying may necessitate the use of larger rock (riprap) on particular portions of the pile.

TABLE 2. USLE Estimates of Soil Loss as Reduced by Applying Crushed Stone to the Soil Surface $(a)$

\begin{tabular}{|c|c|c|}
\hline Site and Soil Type & $\begin{array}{l}\text { Soil LoS } \\
\text { LS-3 } \\
\text { Without Stone }\end{array}$ & $\begin{array}{l}\mathrm{cm} / 1000 \text { yr } \\
\text { LS-3+539 MT/ha } \\
\text { Crushed Stone }\end{array}$ \\
\hline Shiprock, Los sandy loam & 90.27 & 1.93 \\
\hline Rifle, Potts 10am & 47.24 & 1.68 \\
\hline $\begin{array}{l}\text { Mexican Hat, Nakai very } \\
\text { fine sand loam }\end{array}$ & 18.42 & 0.43 \\
\hline Durango, Falfa clay loam & 14.45 & 1.92 \\
\hline $\begin{array}{l}\text { Shiprock, Fruitland } \\
\text { sandy loam }\end{array}$ & 14.33 & 0.49 \\
\hline
\end{tabular}

(a) The sites shown had the highest soil loss rates of those sampled. Stone size is $0.64-$ to $1.27-\mathrm{cm}$ diameter. $\mathrm{LS}-3=10 \%$ slope for $30.5 \mathrm{~m}$. 
Effects of Biological and Radon Barriers on Vegetation

A test plot was constructed during November 1980 in conjunction with other UMTRAP projects on the inactive tailings pile at Grand Junction, Colorado. Studies conducted at this site focused on:

- the relationship between vegetation and radon barriers

- the interaction between vegetation and the herbicide barriers intended to limit plant root penetration

- the effect of soil depth on vegetation

- soil moisture responses to plant cover.

A primary objective was to evaluate the influence of asphalt emulsion, multilayer earth, and root barrier herbicide treatments on the establishment of a stabilizing vegetative cover. Soil moisture is critical to the establishment and maintenance of vegetation on disturbed sites in arid and semiarid regions, and it is influenced by tailings cover treatments.

The experimental design included the following treatments: soil over tailings, soil over asphalt, soil over asphalt plus herbicide, soil over multilayer earth, and soil over multilayer earth plus herbicide. The asphalt and plain soil treatment consisted of a mounded soil cover ranging in depth from 0.3 to $1.4 \mathrm{~m}$. The soil over the multilayer earth plot was $0.74 \mathrm{~m}$ deep. Soil preparation and seeding were the same for all cover treatments. No significant differences in soil moisture were detected among treatments during three years of study.

Vegetative cover was estimated by species in May, July, and September 1981; and in August 1982 and 1983. The percentage of ground covered by each species was estimated during the sampling periods using the Daubenmire cover scale (Daubenmire 1968).

September samples were analyzed to identify differences in vegetative cover among the types of barrier treatments. The September data were assumed to be most indicative of vegetative establishment and growth. No significant differences related to treatment were found. 
Root distribution studies were conducted at the Grand Junction test plot late in October 1981. Trenches were dug in the overburden over the asphalt seal portion of the plot and over one location above the tailings. Root distributions were estimated by sampling root frequency at depth increments of $20 \mathrm{~cm}$.

Root distributions were not significantly affected by the asphalt seal, depths of the overburden or bulk density of the overburden (bulk density ranged from $\sim 1.20$ to $\left.1.45 \mathrm{~g} / \mathrm{cm}^{3}\right)$. However, roots had penetrated into the surface of the tailings in areas without asphalt. No root penetration damage to the asphalt seal was apparent. The frequency of roots below the $60-\mathrm{cm}$ depth over asphalt and asphalt with herbicide was noticeably less than that at shallower depths.

No significant effects on vegetation or soil moisture from the multilayer or asphalt seals were detected. Depth of overburden ranging from 0.5 to $1.0 \mathrm{~m}$ had no significant effect on vegetation or soil moisture. The Treflan® herbicide used to stop root penetration had no significant effect on vegetation or soil moisture. Plant roots grew throughout the overburden within a year. Effects of Rock Material on Vegetation and Soil Moisture

The objective of UMTRAP research on rock and vegetative covers was to examine the effects of surface rock on vegetation and soil moisture. Four separate investigations were conducted: 1) model simulations comparing the effects of vegetation and rock covers on soil and tailings moisture, 2) a lysimeter study of the effects of rock and vegetation surface covers on soil water loss, 3) a field-scale study comparing the effects of rock cover on soil moisture, and 4) a field-scale study of vegetation and vegetation/rock covers focusing on interactions between vegetation and rock and on soil moisture effects.

Unsaturated zone modeling was used to examine the effects of rock and vegetation covers on moisture within the tailings cover system (Mayer et. al 1981). Findings from the simulation modeling suggest that care must be taken

(2) Registered trademark of the Elanco Company. 
when selecting a surface stabilization system for a tailings pile. The moisture-content response of the tailings pile and cover system can vary radically with different surface treatments. The two cases considered in this study indicate that, under the arid climatic conditions at Grand Junction, the evapotranspiration from a vegetated cover can result in a relatively stable moisture content. A rock cover, however, may increase the moisture content of the tailings pile by significantly reducing evaporation. In fact, moisture storage may increase to the point that drainage occurs.

Once a cover system is selected, the modeling effort should also include an assessment of how the cover system affects radon gas emissions. This capability is developed and can be directiy coupled to the unsaturated flow analysis (Nelson, Gee, and Oster 1980; Mayer, Beedlow, and Cadwell 1981). It is important to consider the effects of atmospheric contamination from uranium mill tailings, as well as the potential for groundwater contamination.

Water loss from lysimeters covered with various types and amounts of rock, vegetation, and rock plus vegetation was compared to loss from bare soil. Lysimeters were constructed of 10-gal galvanized steel cans set into 20-ga? galvanized steel cans and filled with Ritzville silt loam. At the start of each experiment, enough water was added to the lysimeters to equalize their water contents. The experiments were conducted by PNL at the Arid Lands Ecology Project, Hanford, Washington. The following are descriptions of the surface treatments for each experiment.

Experiment 1 (16-21 July 1981)--the effect of stone size on soil water 10ss. Treatments included: 1) bare soil with water added to the lysimeter to maintain the moisture content, 2) 2-cm-dia. crushed stone completely covering the surface, 3) pea gravel completely covering the surface, 4) sand, and 5) bare soil with no addition of water.

Experiment 2 (25 July - 25 August 1981)--the effect of -stone depth on water loss. Three-cm-diameter crushed stone was applied in the following amounts:

- 0 (bare soil)

a $225 \mathrm{MT} / \mathrm{ha}$

- $450 \mathrm{MT} / \mathrm{ha}$ 
- $675 \mathrm{MT} / \mathrm{ha}$

- $900 \mathrm{MT} / \mathrm{ha}$.

Experiment 3 (23 April - 10 May 1982)--the effects of rock and vegetative covers on soil water loss. Treatments included: 1) bare soil, 2) 2-cm-dia. crushed rock applied at a rate of $900 \mathrm{MT} / \mathrm{ha}, 3)$ vegetative cover consisting of cheatgrass (Bromus tectorum; cover ranged from $50 \%$ to $90 \%$ ), and 4) vegetation mixed with 2-cm-dia. crushed rock; vegetation cover was $\sim 25 \%$ and rock was applied at $900 \mathrm{MT} / \mathrm{ha}$. Cheatgrass was planted in September 1981.

Experiment 4 (28 June - 9 July, 13-20 July, 3-9 August, 1982)--Treatments were the same as in Experiment 3 except that sunflowers (Helianthus annuus) were used instead of cheatgrass. This experiment was repeated three times: a) three plants/lysimeter; b) two plants/lysimeter; c) one plant/lysimeter.

Treatments were replicated five times in Experiments 1 and 2, and six times in Experiments 3 and 4.

In Experiment 1 the sand cover lost significantly less water than did bare soil (Table 3). Pea gravel and crushed rock treatments did not differ significantly from bare soil although they tended to lose less water. No significant differences were found in net water loss between bare ground and the various application rates of 2-cm-dia. crushed rock (Experiment 2 ).

The experiments comparing bare soil, rock cover, vegetation cover, and rock/vegetation cover (Experiments 3 and 4) had similar results even though

TABLE 3. Cumulative Water Loss From Lysimeters in Experiment 1, Comparing the Effects of Rock Size on Soil Water Loss

$\begin{array}{ll}\text { Sand } & \text { Mean Water Loss, Ib } \\ \text { Pea gravel } & 2.60(\mathrm{a}) \\ \text { 2-cm-dia. rock } & 4.65(\mathrm{a}, \mathrm{b}) \\ \text { Bare soil } & 5.00(\mathrm{a}, \mathrm{b}) \\ \text { Bare soil (water added) } & 6.80(\mathrm{~b}) \\ & 7.50(\mathrm{~b})\end{array}$

(a, b) Treatments with common letters do not differ significantly $(\alpha<0.05)$. 
seed gemination by providing favorable microsites. Rock covers will reduce evaporation and, consequently, more water will be available for plant growth.

A field study was conducted to evaluate the effect of vegetation and rock covers on soil moisture (Kirkham, Beedlow, and Gee 1982). The cover system used in this study, the multilayer radon barrier (Figure 9), consists of a layer of wet clay/gravel mix followed by a capillary barrier of washed rock and a surface layer of fill soil (Gee et al. 1981); however, the results are applicable to cover designs using stabilized earth fill.

Rock cover increased soil moisture levels while the vegetation treatment showed decreased moisture content over time (Table 5). This decrease in available moisture indicates that moisture was removed by evapotranspiration.

Volumetric moisture data collected from the $30-\mathrm{cm}$ depth indicate higher levels of moisture in February than in July (Table 6 ). The highest $30-\mathrm{cm}$ soil moisture levels occurred beneath the rock cover, as expected. The $60-\mathrm{cm}$ soil moisture was highest in July, with the rock cover treatment again having the highest value. The vegetation cover did not appear to extract the moisture from the $60-\mathrm{cm}$ soil depth. The August $1982 \mathrm{plant}$ cover estimate was $18 \%$, with a variability of $13 \%$. The primary species of plants at the site were Agropyron spp. (wheatgrass), Amaranthus rexoflexis (red root pigweed), Salsola kali (Russian thistle), and Kochia scaparia (summer cypress).

This study demonstrates on a field scale that unvegetated rock covers will allow moisture to accumulate in tailings covers. These conclusions support the simulation and lysimeter studies. Accumulation occurs in the absence of vegetation even at arid sites such as Grand Junction. To minimize moisture accumulation, stabilization design using rock should include vegetation, which should be established as soon as possible after closure.

Thin rock covers that allow plant growth are likely to al ter the characteristics of the soil, especially near the surface. Soil characteristics altered by surface layers of rock can affect the structure and response of vegetation. Plant attributes that could be affected include seed germination, size of plants, vigor, woodiness, root depth, reproduction, and susceptibility 
cheatgrass was used in Experiment 3 and sunflowers were used in Experiment 4 (Table 4). No significant differences in net water loss were found between vegetation treatments and vegetation/rock treatments, except in Experiment $4 \mathrm{~b}$. - Experiment $4 \mathrm{~b}$ was shorter than Experiments 3 and $4 \mathrm{a}$ and the plants were younger than those in 4c. Bare soil lost significantly less water than rock/vegetation and vegetation treatments in all cases but one (Experiment 3), but the loss from bare soil was always significantly greater than from rock cover treatments. Water loss from rock treatments was always far less than from the other treatments.

The results of this study support the findings of simulation studies on the effects of rock and vegetative covers on uranium mill tailings (Mayer et a1. 1981). Rock covers reduce soil water loss dramatically and could lead to water accumulation and drainage from a tailings site.

Rock covers that are revegetated appear to facilitate rates of water loss that are similar to vegetation covers. Uranium mill tailings covered with a rock/vegetation cover are not likely to accumulate more moisture than the surrounding soil unless water catchment structures are created in the cover.

The implication for site management is that in areas where vegetation is too sparse (extremely arid regions) to stabilize the cover material, rock/ vegetation combinations can provide additional erosion protection while preventing moisture accumulation. In some areas rock covers may enhance vegetation establishment and growth. The rough surface of the rock cover may benefit

TABLE 4. Cumulative Water Loss from Lysimeters in Experiments 3 and 4, Comparing the Effects of Rock and Vegetative Covers on Soil Water Loss

\begin{tabular}{|c|c|c|c|c|}
\hline \multirow[b]{2}{*}{ Treatment } & \multicolumn{4}{|c|}{ Mean water Loss, Ib } \\
\hline & 3 & $4 a$ & $4 b$ & $4 c$ \\
\hline Bare soil & $13.38^{(a)}$ & $9.29(a)$ & 8.79 (a) & $9.25^{(a)}$ \\
\hline Rock cover & $2.83^{(b)}$ & $1.96^{(b)}$ & $1.79^{(b)}$ & $3.08^{(b)}$ \\
\hline Vegetation & $18.50(a, c)$ & $12.00^{(c)}$ & $12.75^{(c)}$ & 13.9 (c) \\
\hline Vegetation and rock & $15.71^{(c)}$ & $11.83^{(c)}$ & 11.04 & 14.49 (c) \\
\hline
\end{tabular}

$(a, b, c)$ Treatments with common letters do not differ significantly $(\alpha<0.05)$. 


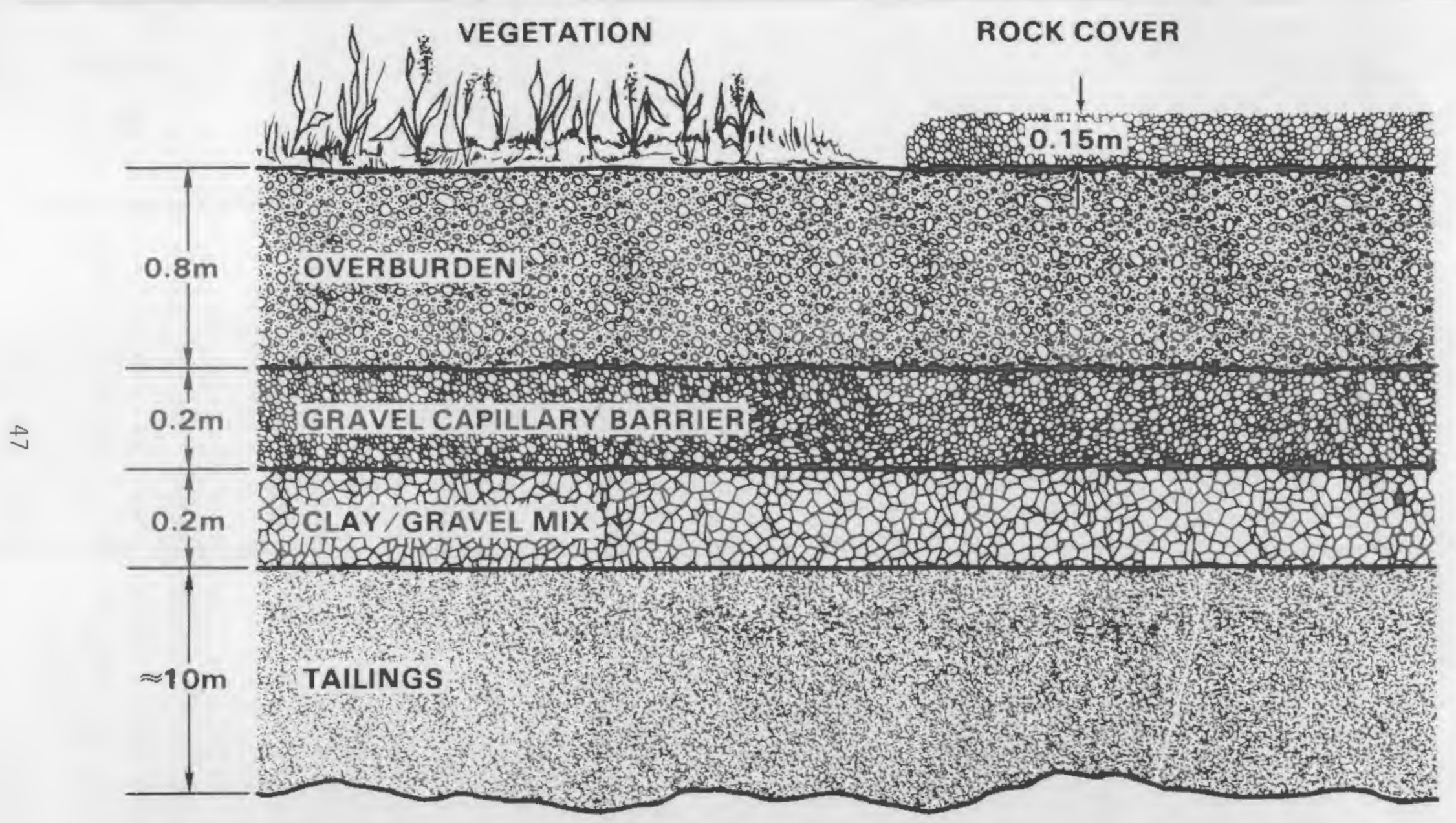

FIGURE 9. Multilayer Radon Barrier 
TABLE 5. Matric Potential in Soils Under Vegetation and Rock Cover Treatments

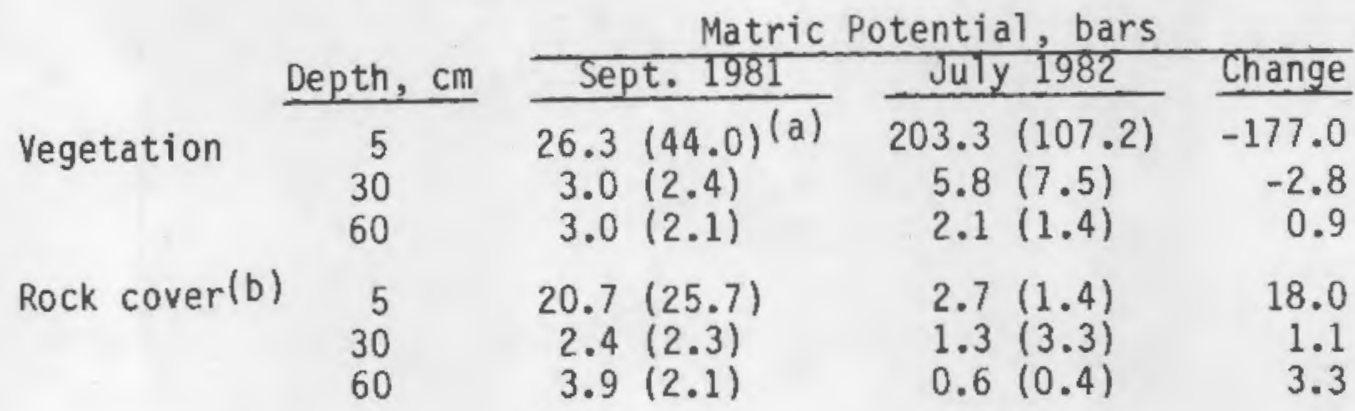

(a) \pm one standard deviation.

(b) Rock was applied in November 1981.

TABLE 6. Volumetric Moisture Content at Two Depths of the Test Plot for Two Dates in 1982

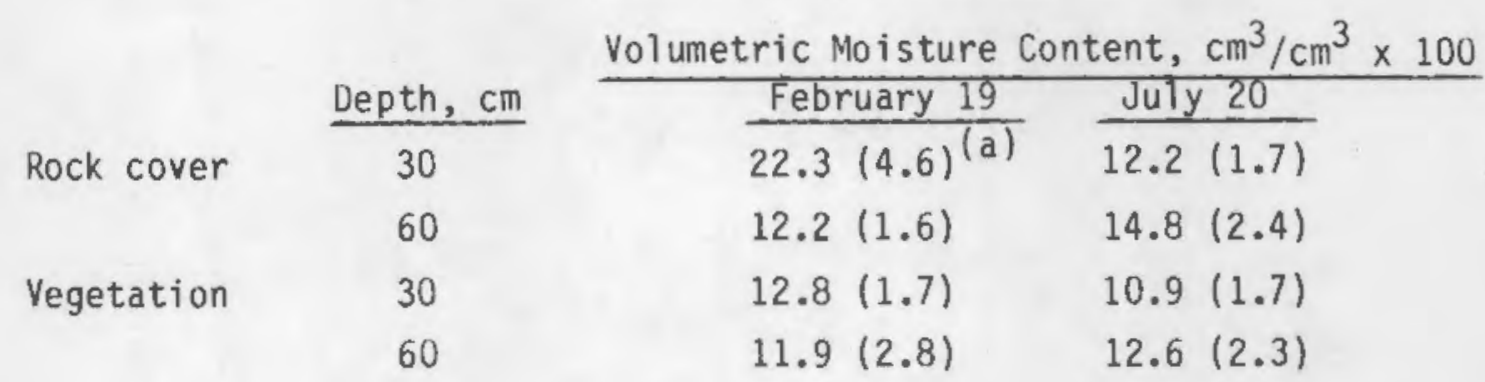

(a) Percent moisture ( \pm one standard deviation).

to stress. As a result of applying rock material to the surface, the species composition may differ from that of the same or similar soil without surface rock. Under natural conditions, rocky soils typically support different types of plants from those found in soils without substantial amounts of rock. In the West, rocky, gravelly soils generally favor woody and forb species over perennial grasses, while even-textured loams or silty soils favor such grasses. Clay soils typically have higher salt content and favor salt-tolerant forbs and shrubs.

Rock covers used to stabilize cover material could result in the establishment of vegetation composed primarily of shrubs and forbs over the long term. This type of vegetation is typically deep-rooted (Grime 1979) and could 
intrude into tailings. The following is a summary of a report (Beedlow and Carlile 1984) on a field-scale experiment designed to: 1) determine if soil covered with rock material similar to that likely to be used on tailings affects the kind and extent of vegetation, 2) evaluate the success of seed imixtures and transplants when surface rock is used, and 3) examine the effects of vegetation and vegetation/rock covers on soil moisture.

Total cover on the test site changed negligibly from the first growing season to the next. However, after the second growing season, weed cover was markedly reduced while the cover of perennial shrubs and grass increased. The decrease in plant cover of ten seen on revegetation sites after irrigation has stopped did not occur. Possible reasons for the sustained cover are that:

1) the plant species used were adapted to the climate and soils of the site, 2) irrigation was applied to supplement the fall rains (a period of seed gerinination for many species) and only as needed to keep the young plants alive during the first summer, and 3 ) the vegetation cover was not supported at abnormally high levels by excess irrigation. Irrigation can promote the establishment of perennial grasses and shrubs. Perennial grasses and, to some extent, shrubs are most desirable for soil stabilization because they are longlived and their more extensive root systems provide greater soil stability than forbs and annual weeds. Proper use of irrigation could permit the establishinent of a protective cover of vegetation within a year of seeding on tailings piles.

Relative to soil and cobble, pit-run rock was associated with increased cover of weeds, shrubs and forbs and decreased grass cover. Total cover was also highest on rock. Rock material placed on tailings piles to increase surface stability is likely to favor vegetation composed primarily of shrubs and forbs. Shrubs and forbs typically have deeper root systems than do grasses; cover designs must therefore consider the increased risk of root penetration when surface rock is used. Cobble generally had an intermediate affect on vegetation and could be useful in some surface cover designs. Additionally, observations suggest that the pit-run rock material may be more susceptible to erosion than cobble. Run-off channels were found on the rock cover after the longer irrigation treatments; none were found in the cobble or the soil on comparable slopes. 
The most successful planting treatment was that of seeding predominantly with shrubs and forbs regardless of whether surface rock was applied. The climate and soils in the vicinity of the test site support vegetation communities that are shrub dominated. Thus, the climatic and edaphic conditions as well as rock cover tend to favor shrub and forb growth.

Efforts should be made to establish vegetation on tailings piles in semiarid and arid areas rather than relying on natural colonization. Treatments that did not receive seed had significantly less cover than seeded plots. The natural establishment of perennial species in arid areas is typically episodic, depending on favorable temperature and soil moisture conditions that result from the timing, amount, and duration of precipitation (MacMahon and Schimpf 1981). Rainfall becomes less predictable the drier the climate (Bailey 1981). Consequently, favorable conditions for plant establishment are less likely to occur on a regular basis in drier climates. However, by seeding and irrigating properly during the first growing season, these conditions can be created.

An al ternative treatment to seeding covered tailings piles is placing rock material on the surface and allowing natural plant colonization. This alternative could leave the surface with a less-than-achievable plant cover for considerable lengths of time. Annual weedy species are likely to be abundant when moisture conditions permit, but perennial species will become established slowly. Unseeded tailings covers in arid areas may experience widely fluctuating vegetation cover due to the population fluctuations of annual weeds. The best procedure is to establish vegetation on the surface whether or not rock is applied.

Unvegetated rock covers reduce soil water loss, which could lead to accumulation and drainage from tailings piles (Mayer, Beedlow, and Cadwell 1981). The present work shows that rock covers that support vegetation do not appear to significantly increase soil moisture relative to vegetation alone. Tailings covered with rock plus vegetation are not likely to accumulate more moisture than soil in the surrounding area unless water catchment structures are created on the cover.

Cline et a1. (1982) present results of research which developed and evaluated the effectiveness of physical and chemical barriers designed to prevent 
plant and animal breachment of uranium mill tailings containment systems for an extended period of time. A polymeric carrier/biocide delivery (PCD) system was developed and tested in the laboratory, greenhouse, and field. A continuous flow technique was established to determine the release rates of the biocides from the PCD systems; polymeric carrier specifications were established. Studies were conducted to determine effective biocide concentrations required to produce a phytotoxic response and the relative rates of phytotoxin degradation resulting from chemical and biological breakdown in soils. The final PCD system developed was a pelletized system containing $24 \%$ trifluralin, $18 \%$ carbon black, and $58 \%$ polyiner. Pellets were placed in the soil at the Grand Junction tailings site at $2.5-\mathrm{cm}$ and $5-\mathrm{cm}$ intervals. Data obtained in the field determined that the pellets released enough herbicide to the soil layer to stop root elongation past the barrier.

Physical barriers to subsurface movement of burrowing animals were investigated ( $\mathrm{Cline}$ et al. 1982). Sma11 crushed stone ( 2 to $4 \mathrm{~cm}$ dia.) placed over asphalt emulsion and multilayer soil seals proved effective as barriers to a small mammal (the ground squirrel) but were not of sufficient size to stop a larger animal (the prairie dog). No penetrations were made through the asphalt emulsion or the clay layer of the multilayer soil seals by either of the two mammals tested. A literature survey was prepared and published on the burrowing habits of the animals that may be found at tailings sites (Gano and States 1982).

Most of the tailings sites, with one exception, are located in the western states and are characterized by arid climates with neutral to basic soils. The pelletized PCD system does not affect soil water movement; the trifluralin remains in a thin layer and is stable even under heavy irrigation. For this reason, the PCD system can be applied successfully in most climatic regimes. The pellets should be placed in a uniformly spaced layer $\sim 1 \mathrm{~m}$ below the soil surface.

The following procedures can be used in designing an animal intrusion barrier: 
- identify the species of burrowing animals native to the specific site

- determine their body weights and burrowing habits

- design a stone barrier accordingly.

A $15-\mathrm{cm}$ layer of $\sim 2-$ to $4-\mathrm{cm}-\mathrm{dia}$. crushed stones placed $45 \mathrm{~cm}$ below the soil surface will stop ground squirrels weighing $300 \mathrm{~g}$ or less. However, prairie dogs with average body weights of $2 \mathrm{~kg}$ can dig through crushed stone of this size. Actual size of stones to be used in a barrier for larger animals will have to be field tested.

If a properly designed asphalt emulsion seal at least $7 \mathrm{~cm}$ thick is used, plant and animal barriers are not needed as long as the seal maintains its integrity ( $C$ ine et al. 1982). Both the PCD system as a root barrier and the stone layer as an animal barrier are recormmended for use with multilayer earth seals, as plants and animals may damage the integrity of earth or clay seals.

ANALYTICAL PREDICTION METHODS

Designing protective covers for uranium mill tailings requires information gathered directly from a particular site and from mathematical models. Presented in this section are methodologies applicable to designing protective covers.

Erosion

A means to quantify the erosion stresses likely to be acting on an impoundment is critical for designing long-term protective covers. The development of design specifications requires estimates of erosion rates, as does the selection and justification of particular cover schemes. In general, soil loss models have been developed for agricultural purposes. The adaptation of erosion models to long-term stabilization of waste sites has been initiated only recently (e.g., Nyhan and Lane 1982).

Regardless of the computational method used to predict erosion stresses at a given pile, model implementation and interpretation of results must be based on a thorough knowledge of geomorphological processes at that site. During site reconnaissance, a qualitative analysis of prevailing and potential types 
of erosion can be made by inspecting the pile and surrounding land forms. For example, the presence and extent of rills and gullies at a site could indicate the significance of erosion at that site.

Following the reconnaissance, appropriate computational methods can be selected and the necessary site data can be collected. Required site data will vary depending upon the model selected. Several models will probably be necessary to develop cover designs for tailings.

Because all erosion models are highly sensitive to climatic variables, criteria for estimating future climatic conditions need to be defined. Designing a cover to resist the average amount of precipitation falling in 100 years is quite different from designing a cover to withstand a 100-year storm. Current methods of predicting erosion are not capable of analyzing all of the possible combinations of events that can occur. Over time periods in which climatic data have been recorded (10 to 100 years), we can estimate event sequences on a statistical basis with some confidence. However, climatic conditions for periods longer than 100 years must take long-term climatic changes into account or rely on "worst-case" scenarios. "Probable maximum" events have been prescribed by the NRC for determining worst-case erosion stresses at new and existing mills (NRC 1982). This method is very conservative and may lead to higher costs for protective covers, but it has precedence. Other statistically-based events such as the 100-year storm may also be appropriate. However, design climatic conditions must be defined before erosion models can be used for anything other than relative comparisons.

Tailings piles are often located on flood plains or along surface-water pathways, making stream erosion a serious long-term problem. The most common method of protecting against flood damage is the use of rock riprap. Walters (1982) discusses rock riprap design methods and their applicability for longterm protection of tailings against flood damage. Tailings piles present design problems, not previously encountered, that are associated with irregular shapes and long-term protection requirements. Specifically these include: 1) selection of design flood criteria, 2) rock durability over long time periods, and 3) the extent of local scour from high-velocity flows. Additional information can be found in Nelson et al. (1983). 
A document prepared for the NRC (Bander 1982) reviews the mechanics of wind erosion and predictive models. The model that best describes the wind erosion of a tailings pile is the equation developed by Chepil (Skidmore 1974), which contains more wind-erosion factors pertinent to tailings piles than any other model reviewed. Charts and graphs for obtaining the various factors in the equation, and the development of a computerized program, make the equation fairly easy to use.

The amount of soil lost from a covered tailings pile as a result of wind erosion over many years is provided by the wind erosion equation. However, for any particular year, the amount of soil lost can vary, depending on the wind and precipitation for any particular location. Considered on a seasonal basis, the variations from average values would be even greater. One way to improve the accuracy of the equation and to estimate the variability of the annual values predicted would be to incorporate probability functions for some of the dynamic variables (Skidmore 1974).

Walters (1983) discusses the processes involved in overland erosion and appropriate models for evaluating this form of erosion on tailings piles. The models are of two basic types: 1) regression models, such as USLE and MUSLE, (a) which are derived from empirical data and interpret input-output relations using simplified forms that may or may not have physical significance; and 2) physical process simulation models, such as ARM, CREAMS, and MULTSED, (b) which formulate the processes controlling erosion. Regression models are simple to use and can accommodate regional types of data. Process models require computers and use much more detailed input data. Limitations of the regression models result from their empirical nature. Regression models are most accurate for the specific locations where soils and climate data used to construct the models were collected. Large errors may occur when regression models are used for sites where no empirical data exist. The major limitations of process models are their extensive data and computational requirements. Some process models also use

(a) MUSLE--Modified Universal Soil Loss Equation.

(b) ARM--Agricultural Run-off Management Model

CREAMS--Chemical, Run-off, and Erosion from Agricul tural Management Systems

MULTSED--Multiple Watershed Water and Sediment Routing. 
empirically derived relationships in some portions of their sediment yield calculations. Again, where empirically derived factors are used, the relevance to a particular site is highly dependent on the experience and skill of the model user.

Both types of models should be used for cover design. Regression models could be used to quickly assess the erosion potential of the impoundment by providing relative estimates of erosion on various parts of the tailings (e.g., slopes and tops) and for various segments of the watershed. For tailings located on hydrologically simple landscapes such as plains, the regression models may suffice. Regression models are also appropriate for selecting materials for erosion protection. The relative erosion rates of different soil materials and slopes can be evaluated quickly with simple regression models.

Complex hydrological landscapes are common at tailings sites in the West. Design of protective covers in these areas must account not only for run-off from the tailings themselves but also from the surrounding watershed. Many of the tailings piles are located beside streams that present potential flood danger. Under flooding conditions, hydraulic and process models should be used for designing protective covers (Walters 1982).

\section{Biotic Intrusion}

Before methods to exclude plants and animals from tailings are designed, the actual, site-specific biotic intrusion problem must be detemined. Biotic intrusion facilitates the release of contaminants by 1) active transport of tailings and contaminants to the surface by physically moving tailings or incorporating contaminants into tissues, 2) transport enhancement where radon emission and water movement are increased by burrowing and root growth, or where burrowing activity increases erosion of the cover material, and 3) secondary transport where contaminants are spread by plants and animals after reaching the surface by active transport or as the result of transport enhancement.

Active transport can be evaluated by computer programs such as BIOPORT (McKenzie et al. 1982), which takes both plants and animals into consideration, 
and is flexible enough to account for various plant and aminal communities, plant succession, and animal activity over time. Secondary transport must be qualitatively evaluated, as no computational models yet exist.

Transport enhancement due to biotic intrusion can be evaluated using existing erosion, soil moisture, and radon flux models. The effect that burrowing animals have on soil loss is related to the amount of soil they bring to the surface. Water infiltration is related to both burrowing activity and root distribution. Radon flux is related to the extent of burrowing, the type of animals burrowing, and plant root distribution.

The major obstacle to using existing models for quantitative analyses of the effects of biotic intrusion is the gathering of necessary input data. Data bases characterizing burrows are presented by Gano and States (1982) and Cline et a1. (1982). No comprehensive data base is available for rooting characteristics of plant species, although a significant anount of rooting literature exists. Collecting site-specific data will in any case be necessary.

Because the extent to which biotic intrusion is a problem is not known, preliminary assessment followed by quantitative analyses is suggested before developing design specifications. Assessment of plant and animal species that could cause intrusion problems can be made from the literature and from site visits. If potential problems exist, a preliminary modeling study can be made using existing data. If the preliminary modeling study suggests that precautions must be taken to prevent biotic intrusion, detailed site data can be collected to produce design specifications. Site-specific evaluation by experts should coincide with modeling efforts to avoid costly misinterpretations.

Soil Moisture

Computer modeling using the UNSAT water flow code has been used in UMTRAP research and provides a useful tool for predicting water movement and storage in soils (Simmons and Gee 1981; Mayer et al. 1981). However, detailed input data are required for operation of UNSAT. While UNSAT may require information too detailed for developing conceptual designs, it will certainiy be applicable for final design plans. 
Simplified calibrations of long-term soil moisture (Gee, Nielson, and Rogers 1984) are appropriate for conceptual designs. These calculations are based upon empirical relationships between soil and $\mathrm{cl}$ imate characteristics. 
RELATED RESEARCH

Research other than that sponsored by UMTRAP relevant to long-term stabilization of uranium mill tailings is being conducted at PNL and elsewhere. The following is a partial listing of such research.

- URANIUM RECOVERY RESEARCH SPONSORED BY THE NUCLEAR REGULATORY COMMISSION--PNL

The overall objective of this research is to provide NRC and their licensees with technical guidance on several issues related to management of wastes from active and inactive uranium mills and in situ recovery operations. Principal issues addressed in these studies are: design and performance of radon suppression covers; incentives and constraints for using protective covers, and designs for armoring tailings pile radon suppression covers; short-term stabilization options for controlling windblown particles; leachate movement in soil; tailings dewatering and consolidation; deliberate disposal below the water table; neutralization incentives; contamination control and restoration for in situ uranium recovery; and environmental measurements, instrumentation, and protocol for assessing the radioactive contamination associated with uranium milling and mill tailings.

of particular interest is a major task within this program, entitled "Long-Term Stabilization." An engineering handbook on the protection of decomnissioned uranium tailings impoundments from long-term erosion by wind and water is being prepared. It will include a technical/economic evaluation of riprap design procedures, an evaluation of watershed models for estimating potential surficial erosion around the tailings pile, and criteria to estimate embankment slope stability. 
- RAdiOECOLOGY OF NUCLEAR FUEL CYCLE--PNL

This study, sponsored by the DOE, is designed to provide information to help assess the environmental impacts and certain potential human hazards associated with nuclear fuel cycles. This study will facilitate the development of a sufficient data base to define and quantify biological transport routes which will permit credible predictions and assessment of routine and potential large-scale releases of radionuclides and other toxic materials. These data, used in assessment models, will increase the accuracy of estimating radiation doses to man and other bjota. Information obtained from existing storage and disposal sites will provide a meaningful radioecological perspective with which to improve the effectiveness of waste management practices. Results will provide information to determine if waste management procedures on the Hanford Site have caused ecological perturbations and if so, the source, nature, and magnitude of such disturbances.

- eVAluating Biological tRANSPORT OF RADIONUCLIDES at COMMERCiAL LOWLEVEL WASTE BURIAL SITES--PNL

This NRC-sponsored work is intended to develop and demonstrate methods for evaluating the long-term impact of biological processes at comercial low-level waste disposal sites. As part of this effort, order-of-magnitude estimates of doseto-man resulting from animal burrowing activity and p1ant translocation of radionuclides were developed. Reference commercial low-level waste sites in both arid and humid areas of the United States were examined. Dose-to-man estimates resulting fron biotic transport are compared with doses calculated from human intrusion exposure scenarios. Doseto-man estimates, as a result of biotic transport, are of the same order of magnitude as those resulting from a more comonly evaluated human intrusion scenario. The reported lack of 
potential importance of biotic transport at low-level waste sites in earlier assessment studies is not confirmed. These results indicate that biotic transport has the long-term potential to mobilize radionuclides. Therefore, biotic transport should be carefully evaluated during burial site assessment.

- Shallow ground disposal of loW-LEVEl waSte: RELEASE/TRANSPORT IN ARID LANDS--PNL

This DOE-sponsored project will monitor and characterize the transport of liquid and vapor phase fluids, and associated waste materials, at a shallow land burial test site. Monitoring activities will assess available instrumentation and current manitoring methods and define an optimal monitoring system. This technology will assist in the effective design of waste burial sites by transmitting the information obtained to the National Low-Level Waste Management Prograin for inclusion in the Shallow Land Burial Manual.

Characterization of transport processes will provide a better understanding of the magnitude of water movement to the water table or to the soil surface and contribute to the design of new shallow land burial sites. This task involves assessing the mass and energy balance of arid region radioactive waste disposal sites and deternining rates of specific radionuclide/ water transport in the partially saturated ground zone.

- Shallow-land buRial technOLOGY: arid laNDS--los alamos national LABORATORY

The purpose of this DOE-sponsored project is to continue the work on biointrusion barriers, migration barriers, and groundand surface-water management technologies for application at 10w-level waste sites. 
- GEOMORPHIC PROCESSES IN RELATION TD URANIUM MILL TAILINGS--COLORADO STATE UNIVERSITY (CSU)

CSU is conducting investigations for NRC on the long-term stability of nuclear waste disposal sites with emphasis on geomorphic stability. Methods for assessing geomorphic hazards are being identified or developed.

a DESIGN CONSIDERATIONS FOR LONG-TERM STABILIZATION OF URANIUM MILL TAILINGS IMPOUNDMENTS--CSU

CSU has been investigating the degree of confidence with which long-term reclamation plans can be expected to remain effective. The design efforts that are required to provide stability for various time periods have been reviewed. The various failure mechanisms and mitigating measures are being identified. 
REFERENCES

Bagnold, R. A. 1954. The Physics of Blown Sand and Desert Dunes. Methuen and Co., Ltd., London.

Bailey, H. P. 1981. "Climatic Factors of Deserts." In Water in Desert Ecosystems, eds. D. D. Evans and J. L. Thames, Pp. 13-41. Dowden, Hutchinson and Ross, Inc., Stroudsburg, Pennsylvania.

Bander, T. J. 1982. Literature Review of Models for Estimating Soil Erosion and Deposition from Wind Stresses on Uranium MiTT Tailings Covers. NUREG/ CR-2768, PNL-4302, Pacific Northwest Laboratory, Richland, Washington.

Barbour, M. G., and D. Y. Diaz. 1973. "Larra Plant Communities on Bajada and Moisture Gradients in the U.S. and Argentina." Vegetation 28:335-352.

Beedlow, P. A., and D. W. Carlile. 1984. "Long-Term Stabilization of Uranium Mill Tailings: Effects of Rock Material on Vegetation and Soil Moisture." In Proceedings of the Sixth Symposium on Management of Uranium Mill Tailings, Low-Level Waste, and Hazardous Waste, February 1-3, 1984. Colorado State University, Fort Collins, Cotorado.

Beedlow, P. A., and M. C. McShane. 1984. "The Suitability of Vegetation for Erosion Control on Uranium Mill Tailings: A Regional Analysis." In Proceedings of the Sixth Symposium on Management of Uranium Mill Tailings, LowLevel Waste, and Hazardous Waste, February I-3, 1984, Colorado State University, Fort Collins, Colorado.

Beedlow, P. A., M. C. Mc Shane, and L. L. Cadwell. 1982. Revegetation/Rock Cover for Stabilization of Inactive Uranium Mill Tajlings Disposal Sites: A Status Report. DOE/UMT-0210, PNL-4328, Pacific Northwest Laboratory, Richland, Washington.

Brady, N. C. 1974. The Nature and Properties of Soils. 8th ed. MacMillan \& Co., New York.

Buelt, J. L., et al. 1983. Liner Evaluation for Uranium Mill Tailings: Final Report. DDE/UMT-0216, PNL-4842, Pacific Northwest Laboratory, Richland, Washington.

Cline, J. F., et al. 1982. Long-Term Biobarriers to Plant and Animal Intrusions of Uranium Tailings. DOE/UMT-0209, PNL-4340, Pacific Northwest Laboratory, Richland, Washington.

Cline, J. F., K. A. Gano, and L. E. Rogers. 1981. "Loose Rock as Biobarriers in Shallow Land Burial." Health Physics 39:497-504.

Cooke, R. U., and A. Warren. 1973. Geomorphology in Deserts. University of California Press, Los Angeles, Californiä. 
Daubenmire, R. F. 1968. Plant Communities, a Textbook of Plant Synecology. Harper \& Row, New York.

Douglas, G. W. 1972. "Subalpine Plant Communities of the Western North Cascades, Washington." Arctic and Alpine Research 4:147-166.

Duffy, W. D., and T. W. Gardner. 1983. "Soil Characterization, Headcut Erosion and Landout Classification in the San Juan Basin." In Chaco Canyon Country--American Geomorphological Field Group Field Trip Guỉdebook, eds. 5. G. Wells, D. W. Love, and T. W. Gardner, Pp. 67-79. American Geomorphological Field Group, Alburquerque, New Mexico.

Environmental Protection Agency. 1978. Environmental Protection Criteria For Radioactive Waste. U.S. Environmental Protection Agency, Washington, D.C.

Environmental Protection Agency. 1982. Final Environmental Impact Statement for Remedial Action Standard for Inactive Uranium Processing Sites 140 CFR T92). Volume 1, EPA 520/4-82-013-1, U.S. Environmental Protection Agency, Washington, D.C.

Environmental Protection Agency, 1983. Environmental Standards for Uranium and Thorium Mill Tailings at Licensed Commercial Processing Sites, 40 CFR 192, FinaT Action. U.S. Environmental Protection Agency, Washington, D.C.

Fitzner, R. E., et al. 1979. Characterization of the Hanford 300 Area Burial Grounds Task IV--Biological Transport. PNL-2774, Pacific Northwest Laboratory, Richland, Washington.

Foley, M. G. 1983. Uranium Recovery Research Sponsored by the Nuclear Regulatory Commission at Pacific Northwest Laboratory: Annual Progress Report, May 1982 to May 1983. PNL-4608-3, Pacific Northwest Laboratory, Richland, washington.

Gano, K. A., and J. B. States. 1982. Habitat Requirements and Burrowing Depths of Rodents in Relation to ShaTTow Waste BuriaT Sites. DOE/UMT-0208, PNL-4140, Pacific Northwest Laboratory, Richland, Washington.

Gee, G. W., et al. 1981. "Radon Control by Multilayer Earth Barriers." In Proceedings of the Fourth Symposium on Uranium Mill Tailings Management, October 26-27, 1981. Colorado State University, Fort Collins, Colorado.

Gee, G. W., K. K. Nielson, and V. C. Rogers. 1984. "Predicting Long-Term Moisture in Earthen Covers." In Proceedings of the Sixth Symposium on Management of Uranium Mill Tailings, Low-Level Waste and Hazardous Waste, February 1-13, 1984. Cotorado State University, Fort Collins, Colorado.

Gregory, K. J., ed. 1977. River Channel Changes. John Wiley and Sons, New York. 
Grime, J. P. 1979. Plant Strategies and Vegetation Processes. John Wiley and Sons, New York.

Hakonson, T. E., J. L. Martinez, and G. C. White. 1982. "Disturbance of a Low-Level Waste Burial Site Cover by Pocket Gophers." Health Physics 42:868-871.

Harner, R. F., and K. T. Harper. 1976. "The Rule of Area, Heterogeneity, and Favorability in Plant Species Diversity of Pinyon-Juniper Ecosystems." Ecology 57:1254-1263.

Hartley, J. N., et al. 1983. Radon Barrier Field Test at Grand Junction Uranium Mill Tailings Pile. DOE/UMT-0213, PNL-4539, Pacific Northwest Laboratory, Richtand, Washington.

Kirkham, R. R., P. A. Beedlow, and G. W. Gee. 1982. "Effect of Rock Cover on Multilayer Radon Barrier Effectiveness." Symposium on Uranium Mill Tailings Hanagement, December 9-10, 1982, pp. 409-419. Colorado State University, Fort ColTins, Colorado.

MacMahon, J. A., and D. J. Schimpf. 1981. "Water as a Factor in the Biology of North American Desert Plants." In Water in Desert Ecosystems, eds. D. D. Evans and J. L. Thames, pp. 114-171. Dowden, Hutchinson and Ross, Inc., Stroudsburg, Pennsylvania.

Mayer, D. H., et al. 1981. Radon Diffusion Through Multilayer Earthen Covers: Models and Simulations. PNL-3989, Pacific Northwest Laboratory, Richland, Washington.

Mayer, D. W., P. A. Beedlow, and L. L. Cadwe11. 1981. Moisture Content Analysis of Covered Uranium Mill Tailings. D0E/UMT-0207, PNL-4132, PaCific Northwes $t$ Laboratory, Rich and, Washington.

McCloskey, R. T. 1976. "Community Structure in Sympatric Rodents." Ecology 57:728-739.

McKenzie, D. H., et al. 1982. Relevance of Biotic Pathways to the Long-Term Regulation of Nuclear Was te Disposal: A Report on Tasks I and 2 of Phase 1. WJREG/CR-2675, PNL-4241, VoTs. I and II, PaCific Nor thwest Laboratory, Richland, Washington.

Mi11, A. M., and T. W. Gardner. 1983. "Effects of Aquifer Dewatering on an Ephemeral Stream, San Juan Basin." In Chaco Canyon Country--American Geomorphological Field Group Field Trip Guidebook, eds. S. G. Wells, O. W. Love, and T. W. Gardner, pp. 51-5\%. American Geomorphological Field Group, Alburquerque, New Mexico. Morisawa, M. 1968. Streams, Their Morphology and Dynamics. McGraw-Hill, New
York. 
Ne1son, J. D., et al. 1983. Design Considerations for Long-Term Stabilization of Uranium Mi 11 Tailings Impoundments. NUREG/CR-3397, ORNL-5979, Oak Ridge National Laboratory, Oak Ridge, Tennessee.

Nelson, 3. D., and T. A. Shepherd. 1978. Evaluation of Long-Term Stability of Uranium Tailing Disposal Alternatives. Prepared for Argonne National Laboratory by Colorado State University, Fort Collins, Colorado.

Nelson, R. W., G. W. Gee, and C. A. Oster. 1980. "Radon Control by Multilayer Earth Barriers, 1. Modeling of Moisture and Density Effects on Radon Diffusion from Uranium Mill Tailings." In Proceedings of the Third Symposium on Uranium Mill Tailings Management, November 24-25, 1980, pp. 79-88. Colorado State University, Fort Collins, Colorado.

Nuclear Regulatory Commission. 1980. Final Generic Environmental Impact Statement on Uranium Milling. NUREG-0706, Office of Nuclear Material Safety and Safeguards, D.S. Nuclear Regulatory Comnission, Washington, D.C.

Nuclear Regulatory Commission. 1982. Hydrologic Design Criteria for Tailings Retention Systems. Draft Staff Technical Position WM-8201, Uranium Recovery Licensing Branch, U.S. Nuclear Regulatory Commission, Washington, D.C.

Nyhan, J. W., and L. J. Lane. 1982. "Use of a State of the Art Model in Generic Designs of Shallow Land Repositories for Low-Level Wastes." In Waste Management ' 82 , Proceedings of the 1982 Symposium in Waste Management, March 8-11, 1982. Tucson, Arizona.

0'Brien, P. D. 1981. "The Uranium Mill Tailings Remedial Action Project Technology Development Program." In Proceedings of the Fourth Symposium on Uranium Mill Tailings Management, Oc tober 26-27, 1981. Colorado State University, Fort Collins, Colorado.

O'Farrel1, M. J. 1980. "Spatial Relationships of Rodents in a Sagebrush Community." J. Mammalogy 61:589-605.

Price, M. V. 1978. "The Role of Microhabitat in Structuring Desert Rodent Communities." Ecology 59:910-921.

Schumm, S. A. 1977. The Fluvial System. John Wiley and Sons, New York.

Schumm, S. A., et al. 1982. "Geomorphic Hazards and Uranium-Tailings Disposal." In Proceedings of International Symposium on Management of Wastes from Mining and Mithing. IAEA-SM-262/50, ATbuquerque, New Mexico.

Schumm, S. A., and R. J. Chorley. 1983. Geomorphic Controls on the Management of Nuclear waste. NUREG/CR-3276, U.S. Nuclear Regutatory Commission, Washington, D.C.

Simmons, C. S., and G. W. Gee. 1981. Simulation of Water Flow and Retention in Cover Materials Overlaying Uranium MiT Tailings. PNL-3877, Pacific Northwest Laboratory, Richland, Washington. 
Simmons, D. B., and F. Sentuck. 1977. Sediment Transport Technology. Water Resources Publications, Fort Collins, Colorado.

Skidmore, E. L. 1974. "A Wind Erosion Equation: Development, Application and Limitations." In Proceedings of the Atmosphere-Surface Exchange of Particulate and Gaseous Pollutants Symposium. National Technical Information Service, Springfield, Virginia.

Vogel, S., C. P. Ellington, Jr., and D. L. Kilgore, Jr. 1973. "Wind-Induced Ventilation of the Burrow of the Prairie Dog, Cynomys Ludovicianus." J. Comp. Physiol. 85:1-14.

Voorhees, L. D., et al. 1983. Guidance for Disposal of Uranium Mill Tailings: Long-Term Stabilization of Earthen Cover Materials. NUREG/CR-3199, ORINLIM8685, Oak Ridge National Laboratory, Oak Ridge, Tennessee.

Walters, W. H. 1982. Rock Riprap Design Methods and Their Applicability to Long-Term Protection of Uranium Mill Tailings Impoundments. NUREG/CR-2684, PNL-4252, Pacific Northwest Laboratory, Richland, washington.

Walters, W. H. 1983. Overland Erosion of Uranium Mill Tailings Impoundments: Physical Processes and Computational Methods. NOREG/CR-3027, PNL-4523, Pacific Northwest Laboratory, Richland, Washington.

Walters, W. H., and R. L. Skaggs, 1983. "Long-Term Erosion Problems of Uranium Mill Tailings Impoundments." In Chaco Canyon Country--American Geomorphological Field Group Field Trip Guidebook, eds. S. G. Wells, D. W. Love, and T. W. Gardner. American Geomorphological Field Group, Albuquerque, New Mexico.

Wells, S. G., and D. E. Jeranovic. 1983. "Application of Geomorphology to Surface Coaldlining Reclamation, Northwest New Mexico." In Chaco Canyon Country--American Geomorphological Field Group Field Trip Guidebook, eds. 5. G. Wells, D. W. Love, and T. W. Gardner, PP. 133-149. American Geomorphological Field Group, Alburquerque, New Mexico.

Winsor, T. E., and F. W. Whicker. 1980. "Pocket Gophers and Redistribution of Plutonium in Soil." Health Physics 39:257-262.

Wischmeier, W. H. 1972. Estimating the Soil Loss Equation's Cover and Management Factor for Undisturbed Areas. Sediment-Yield Workshop, Oxford, Massachusetts.

Wischmeier, W. H., and D. D. Smith. 1978. Predicting Rainfall Erosion Losses--A Guide to Conservation Planning. Agriculture Handbook No. 537 , U.S. Department of Agriculture, Washington, D.C.

Wong, T., R. E. Wardwell, and D. Van Zyl. 1984. "Methodology to Evaluate Reclamation Stability of an Inactive Uranium Mill Tailings Impoundment." In Proceedings of the Sixth Symposium on Uranium Mill Tailings Management, Pp. 511-519. Colorado State University, Fort Collins, Colorado. 
Wullstein, L. H. 1978. "Vegetative Stabilization Report," Appendix A, pp. 1-24. In Laboratory Research on Tailings Stabilization Methods and Their Effectiveness in Radiation Containment, eds. P. J. Macbeth, C. M. Jensen, V. C. Rogers, and R. F. Overmyer. Ford, Bacon and Davis Utah, Inc., Salt Lake City, Utah. [Accession Number GJT-21, National Technical Information Service, Springfield, Virginia.]

Yamamoto, T. 1982. A Review of Uranium Spoil and Mill Tailings Revegetation in the Western United States. General Technical Report RM-92, Rocky Mountain Forest and Range Experiment Station, Forest Service, U.S. Department of Agriculture, Washington, D.C.

Young, J. K., L. W. Long, and J. W. Reis, 1982. Environmental Factors Affecting Long-Term Stabilization of Radon Suppression Covers for Uranium Mill Tailings. NUREG/CR-2564, PNL-4193, Pacific Northwest Laboratory, Richland, Washington.

Zellmer, J. T. 1981. Stability of Multilayer Earthen Barriers Used to Isolate Mill Tailings: Geologic and Gotechnological Considerations. DOE7UMT-0202, PNL-3902, Pacific Northwest Laboratory, Richland, Washington. 


\section{DISTRIBUTION}

No. of

Copies

OFFSI TE

27 DOE Technical Information Center

William E. Mott, Director

Environinental Safety Engineering Division

U.S. Department of Energy, EP-14

Hashington, DC 20545

3. E. Baublitz, Director

Division of Remedial Action Projects

Office of Nuclear Waste Management

$\mathrm{J} . \mathrm{S}$. Department of Enerqy NE-301

Washington, DC 20545

E. Delaney

Division of Remedial Action

Projects

Office of Nuclear Waste Management

U.S. Department of Energy NE-301

Washington, DC 20545

D. H. Groelsema

Uivision of Remedial Action Projects

Office of Nuclear Waste Managenent

U.S. Department of Energy NE-301 Washington, DC 20545

\footnotetext{
A. Kluk

Division of Remedial Action Projects

Office of Nuclear Waste

Management

U.S. Department of Energy NE-301

Washington, DC 20545
}

No. of

Copies

M. G. White

Division of Remedial Action Projects

Office of Nuclear Waste Management

U.S. Department of Energy NE-301 Washington, DC 20545

J. White, Chief

Waste Management Branch

U.S. Department of Energy

Richland Operations office

P. 0. Box 500

Richland, WA 99352

E. L. Keller, Director

Technical Services Division

DOE Oak Ridge Operations

Office

P. 0. Box $E$

Oak Ridge, TN 37830

Office of the Assistant Manager

for Energy Research and

Development

DOE Oak Ridge Operations office

P.0. Box E

Oak Ridge, TN 37830

J. A. Morley, Project Manager

Uranium Mill Tailings Project office

Suite 1700

5301 Central Ave. NE

Albuquerque, NM 87108

3. Themelis

Uranium Mill Tailings Project office

Suite 1700

5301 Central Ave., NE

Albuquerque, NM 87108 
No. of

Copies

M. L. Matthews

Uranium Mill Tailings Project Office

Suite 1700

5301 Central Ave., NE

A tbuquerque, NM 87108

R. A. Scarano, Chief

Uranium Recovery License Branch

Mail Station 483-5S

U.S. Nuclear Regulatory Commission

Washington, OC 20555

W. A. Nixon

Office of Nuclear Materials, Safety and Safeguards

Mail Station 396-SS

U.S. Nuclear Regulatory Commission

Washington, DC 20555

G. Gnugnoli

Mail Station 1130-SS

U.S. Nuclear Regulatory Commission

Washington, DC 20555

F. Swanberg

U.S. Nuclear Regulatory Commission

Mail Station 1120-SS

Washington, UC 20555

S. Lichtinan

Criteria and Standards vivision Office of Radiation Programs

Environmental Protection Agency Hashington, UC 20460

R. F. Overmyer

Ford Bacon and Uavis

P.0. Box 8009

Salt Lake City, UT 84108
No. of

Copies

T. E. Hakonson

Los Alamos Scientific Laboratory

P.0. Box 1663

Los Alamos, NM 86544

W. E. Kislieleski

Argonne National Laboratory

9700 South Cass Avenue

Argonne, IL 60439

T. N. Narasimhan

Earth Sciences Division

Lawrence Berkeley Laboratory

Berkeley, CA 94720

D. Lewis

Jacobs Engineering Group, Inc.

Suite 1700

5301 Central Ave. NE

A tbuquerque, NM 87108

K. R. Krishnan

Program Manager

Jacobs Engineering Group, Inc.

Suite 1700

5301 Central Ave. NE

Albuquerque, NM 87108

20 R. Petersen

vocument Control

Jacobs Engineering Groups, Inc.

Suite 1700

5301 Central Ave. NE

Albuquerque, NM 87108

J. Duray

Bendix Field Engineering Corp.

P.0. Box 1569

Grand Junction, CO 81502

0. D. Markham

Radiological and Environmental Sciences Laboratory

P.D. Box 2108

1daho Falls, ID 83401 
No. of

Copies

J. D. Nelson

Colorado State University

211 Weber Building

Fort Collins, CO 80523

F. W. Whicker

Radiology Radiation

Biology Lepartment

Colorado State University

Fort Collins, CO 80521

P. J. Rafferty

Roy $F$. Weston, Inc.

Weston Way

Westchester, PA 19380

J. N. Dybalski

Armak Highway Chemicals

Research Co.

8401 W. 47 th Street

McCook, IL 60525

B. Rawles

Battelle Memorial Institute

Office of Nuclear Waste Isolation

$505 \mathrm{King}$ Avenue

Columbus, OH 43201

V. C. Rogers

Rogers \& Associates Engineering P.0. Box 330

Salt Lake City, UT 84110

D. Mills

Department of Environmental Protection

Commonwealth of Kentucky

18 Reilly Road

Frankfurt, KY 40601
No. of

Copies

ONSITE

2 Richland Operations Office

H. E. Ransom

J. C. White

3 Rockwell Hanford Operations

H. E. McGuire

J. W. Patterson

S. A. Weigman

37 Pacific Northwest Laboratory

P. A. Beedlow (10)

T. D. Chikalla

M. G. Foley

H. O. Freeman

T. E. Gates

G. W. Gee

J. N. Hartley (10)

J. V. Robinson

P. C. Walkup

W. H. Walters

P. L. Whiting

N. Wogman

Technical Information (5)

Publishing Coordination (2) 
, 